\title{
AVALIAÇÃO DO VIGOR DE SEMENTES DE MILHO (Zea mays L.) PELA PRECOCIDADE DE EMISSÃO DA RAIZ PRIMÁRIA
}

\author{
JOSÉ HILARIO HERNÁNDEZ SALGADO
}

Engenheiro Agrônomo

Orientador: Prof. Dr. FRANCISCO FERRAZ DE TOLEDO

Tese apresentada à Escola Superior de Agricultura "Luiz de Queiroz", da Universidade de São Paulo, para obtenção do título de Doutor em Agronomia. Área de concentração: Fitotecnia.

\section{PIRACICABA}

Estado de São Paulo - Brasil

Dezembro, 1996 
Dados Internacionais de Catalogação na Publicação (CIP) DIVISÃo DE BIBLIOTECA E DOCUMENTAÇÃO - Campus "Luiz de Queiroz"/USP

Hernández Salgado, José Hilario Avaliação do vigor de sementes de milho (Zea mays L.) pela precocidade de emissão da raiz primária / José Hilario Hernández Salgado. - - Piracicaba, 1996 $86 p$.

Tese (doutorado) -- Escola Superior de Agricultura Luiz de Queiroz, 1997. Bibliografia.

1. Germinação 2. Milho - Semente - Vigor 3. Raiz 4. Título 


\title{
AVALIAÇÃO DO VIGOR DE SEMENTES DE MILHO (Zea mays L.) PELA PRECOCIDADE DE EMISSÃO DA RAIZ PRIMÁRIA
}

\author{
JOSÉ HILARIO HERNÁNDEZ SALGADO
}

Aprovada em 11. 03. 1997

Comissão julgadora:

Prof. Dr. Francisco Ferraz de Toledo

ESALQ/USP

Prof. Dr. Walter Rodrigues da Silva ESALQ/USP

Prof. Dra. Ana Dionísia da Luz Coelho Novembre ESALQ/USP

Prof. Dr. Antonio Augusto do Lago

IAC

Prof. Dr. João Nakagawa

FCAVUNESP

Prof. Dr. Francisco Ferraz de Toledo Orientador 


\begin{abstract}
DEDICATÓRIA
Para minha mãe, meu pai (in memorian) e aos meus irmãos

que muito contribuíram para a minha formação.
\end{abstract}

Aos professores Dr. Abel Muñoz Orozco e

Dr. Francisco Ferraz de Toledo pelo exemplo e dedicação

na formação de Recursos Humanos nas Ciências Agrícolas.

Às famílias Segatto, Vitti, Rodríguez - Hernández, Torres Cervantes e Centeno - Martínez pela sua amizade, compreensão e ajuda recebida em todo momento.

À minha esposa Luz Elva,

e meus filhos Luís Martin e Daniel Roberto

por compartilhar juntos tempos difíceis e bons e pelo amor que nos une. 


\section{AGRADECIMENTOS}

Quero expressar minha especial gratidão às pessoas e instituições de quem recebi ajuda para a condução desta investigação.

Ao Prof. Dr. Francisco Ferraz de Toledo, pelo constante apoio e orientação; pelas sugestões e pelo tempo e esforço dispensado para a realização desta tese.

À Enga ${ }^{a}$. Agr ${ }^{a}$. Helena Maria Carnignani Pescarin Chamma e Dra. Ana Dionisia da Luz Coelho Novembre, pela valiosa ajuda e sugestões em relação as técnicas de análise de sementes.

Aos funcionários João Elias Jabur Filho, João Batista Bigelli, Carlos Adversi Carlet, João Rodrigues, José dos Reis Lopes Santos, Adilson de Jesus Teixeira, Ananias Ferreira de Souza, Claudinei Martins Valério e Daniel Luiz Theodoro pelo auxílio prestado no Laboratório de Análise de Sementes e ensaios de campo do presente trabalho e à secretaria llze Helena C. de Gáspari das Neves pelos serviços prestados.

À Dra. Sonia M. de Stefano Piedade, do Departamento de Matemática e Estatística da ESALQ , pela seu colaboração e assessoria na parte estatística

Aos Profs. Andres Enrique Lai Reyes e Carlos Fernando Sanches do Centro de Informática na Agricultura da ESALQ, pelo auxilio prestado na elaboração dos gráficos.

À Sementes Agroceres S.A., em especial ao Eng ${ }^{\circ}$. Agr $^{\circ}$. Carlos Alberto Ribeiro Gonçalves pelo fornecimento de sementes utilizadas no presente trabalho.

À Fundação Kellogg, pelo apoio financeiro, em especial aos Drs. Heliodoro Diaz Cisneros, Marcos Kisil e "staff" do Programa Internacional de Bolsas Kellogg (KIFP) pela atenção recebida, tornando possivel a realização do meu programa de estudos de Doutorado.

À Universidade de São Paulo, em especial à ESALQ, Campus Piracicaba, pelas facilidades oferecidas para atingir o programa acadêmico e de pesquisa.

Ao "«Colegio de Postgraduados en Ciencias Agrícolas", do México, pela oportunidade de dar continuidade à minha formação acadêmica e o complemento de bolsa para que eu concluísse esta etapa de minha carreira profissional. 


\section{SUMÁRIO}

Página

RELAÇÃO DE TABELAS E FIGURAS............................ ix

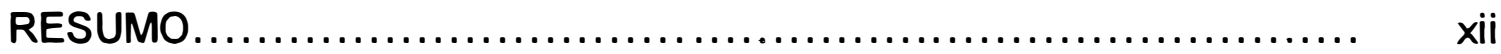

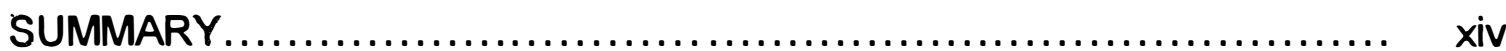

1. INTRODUÇÃO ................................................. 01

2. REVISÃO DE LITERATURA.................................... 03

2.1. Água e o proceso da germinação......................... 03

2.2. Temperatura e o processo da germinação................... 05

2.3. Avaliação da qualidade fisiológica....................... 07

2.3.1. Teste padrão de germinação (TPG)............... 07

2.3.2. Primeira contagem de germinação................ 08

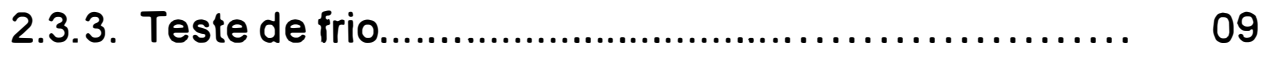

2.3.4. Teste de envelhecimento precoce................ 12

2.3.5. Teste de condutividade elétrica....................... 15

2.3.6. Testes combinados............................. 19

3. MATERIAL E MÉTODOS...................................... 21

3.1. Localização........................................... 21

3.2. Lotes de sementes.................................... 21

3.3. Precocidade da emissão da raiz primária (PER)............ 22

3.4. Outros testes........................................... 23

3.4.1. Teste padrão de germinação (TPG) ............... 24

3.4.2. Primeira contagem de germinação.................. 24 
Página

3.4.3. Teste de emergência das plântulas em areia........ 24

3.4.4. Índice de velocidade de emergência............... 25

3.4.5. Teste de frio com solo......................... 25

3.4.6. Teste de envelhecimeto precoce................. 25

3.4.7. Teste de condutividade elétrica................... 26

3.4.8. Teste de emergência de plântulas em campo........ 26

3.4.9. Altura de plântula................................ 27

3.5. Épocas........................................ 27

3.6. Informações complementares.......................... 28

3.6.1. Teor de água................................. 28

3.6.2. Dados climáticos............................... 28

3.6.3. Dados das condições ambientais do LAS............ 28

3.7. Procedimentos estatísticos........................... 31

3.8. Apêndice............................................. 32

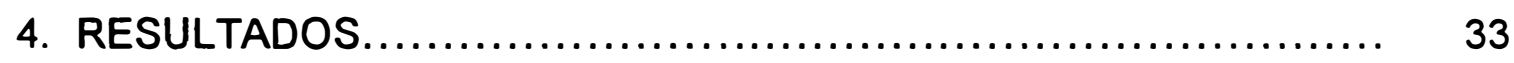

4.1. Precocidade de emissão da raiz primária (PER)........... 33

4.2. Outros testes utilizados.............................. 38

4.2.1. Teste padrão de germinação (TPG)............. 38

4.2.2. Primeira contagem de germinação................ 41

4.2.3. Teste de emergência das plântulas em areia......... 41

4.2.4. Índice de velocidade de emergência em areia...... 44 
Página

4.2.5. Teste de frio com solo.......................... 46

4.2.6. Teste de envelhecimeto precoce................. 46

4.2.7. Teste de condutividade elétrica.................. 50

4.2.8. Teste de emergência de plântulas em campo........ 52

4.2.9. Altura de plântula............................. 52

4.3. Correlações............................................ 55

5. DISCUSSÃO ................................................. 58

5.1. Precocidade de emissão da raiz primária .................. 59

5.2. Outros testes.......................................... 61

5.2.1. Teste padrão de germinação ....................... 61

5.2.2. Primeira contagem de germinação................ 62

5.2.3. Teste de emergência das plântulas em areia......... 63

5.2.4. Índice de velocidade de emergência em areia....... 63

5.2.5. Teste de frio com solo............................ 64

5.2.6. Teste de envelhecimento precoce................. 65

5.2.7. Teste de condutividade elétrica................... 66

5.2.8. Teste de emergência de plântulas em campo......... 66

5.2.9. Altura de plântula............................... 67

5.3. Correlações........................................... 68

5.4. Considerações gerais................................... 69 
Página

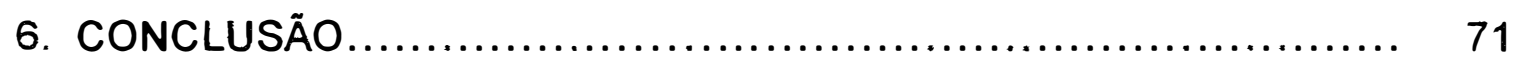

REFERÊNCIAS BIBLIOGRÁFICAS.............................. 72

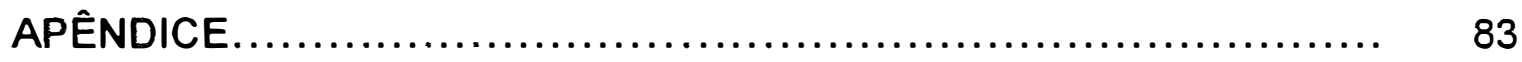




\section{RELAÇÃO DE TABELAS E FIGURAS}

\section{TABELA}

1 Valores médios do teor de água (\%) dos vinte lotes de sementes de milho híbrido AG- 510 avaliados em três épocas. Piracicaba, SP., 1996

2 Esquema da análise da variância dos índices de precocidade de emissão de raiz primária às temperaturas de 20,25 e $30^{\circ} \mathrm{C}$, aplicados sobre os lotes de sementes, por época

3 Esquema da análise da variância dos dados obtidos dos demais testes aplicados sobre os lotes de sementes, por época.

4 Esquema da análise da variância, do conjunto de épocas para cada teste usado sobre os lotes de sementes.

5 Valores médios da precocidade da emissão da raiz primária (PER) a $20^{\circ} \mathrm{C}$, dos vinte lotes de sementes de milho híbrido AG- 510 avaliados em três épocas. Piracicaba, SP., 1996.

6 Valores médios da precocidade de emissão da raiz primária (PER) a $25^{\circ} \mathrm{C}$, dos vinte lotes de sementes de milho híbrido AG- 510 avaliados em três épocas. Piracicaba, SP., 1996.

7 Valores médios da precocidade de emissão da raiz primária (PER) a $30^{\circ} \mathrm{C}$, dos vinte lotes de sementes de milho híbrido AG- 510 avaliados em três épocas. Piracicaba, SP., 1996

8 Valores médios da porcentagem de germinação, do TPG, dos vinte lotes de milho híbrido AG- 510 avaliados em três épocas. Piracicaba, SP., 1996.

9 Valores médios da porcentagem de germinação na primeira contagem, do teste padrão, dos vinte lotes de milho híbrido AG- 510 avaliados em três épocas. Piracicaba, SP., 1996...... 
TABELA

Página

10 Valores médios da porcentagem de emergência de plântulas em areia, dos vinte lotes de milho híbrido AG- 510 avaliados em três épocas. Piracicaba, SP., 1996

11 Valores médios do índice de velocidade de emergência de plântulas em areia, dos vinte lotes de milho híbrido AG- 510 avaliados em três épocas. Piracicaba, SP., 1996.

12 Valores médios da porcentagem de emergência de plântulas do teste de frio (solo + areia) dos vinte lotes de milho híbrido AG- 510 avaliados em três épocas. Piracicaba, SP., 1996.......

13 Valores médios da porcentagem de plântulas normais, do teste de envelhecimento precoce, dos vinte lotes de milho híbrido AG- 510 avaliados em três épocas. Piracicaba, SP., 1996

14 Valores médios da porcentagem de sementes mortas, do teste de envelhecimento precoce, dos vinte lotes de milho híbrido AG- 510 avaliados em três épocas. Piracicaba, SP., 1996.

15 Valores médios ( $\mu \mathrm{mhos} / \mathrm{cm} / \mathrm{g}$ ) do índice de condutividade elétrica, dos vinte lotes de milho híbrido AG- 510 avaliados em três épocas. Piracicaba, SP., 1996.

16 Valores médios da porcentagem de emergência de plântulas em campo, dos vinte lotes de milho híbrido AG- 510 avaliados em três épocas. Piracicaba, SP., 1996.

17 Valores médios da altura de plântula $(\mathrm{cm})$ dos vinte lotes de milho híbrido AG- 510 avaliados em três épocas. Piracicaba, SP., 1996

18 Coeficientes de correlação simples estimados ( $r$ ), entre as caracteristicas avaliadas, calculados com base nos valores médios dos vinte lotes de milho híbrido AG- 510. Piracicaba, SP., 1996. 
1 Valores médios da precipitação pluvial (histograma) e temperatura máxima e mínima $\left({ }^{\circ} \mathrm{C}\right)$ semanais em Piracicaba, SP., no período de agosto de 1995 a julho de 1996.

2 Valores médios da umidade relativa do ar (\%) e temperatura média, máxima e mínima $\left({ }^{\circ} \mathrm{C}\right)$ no ambiente do Laboratório de Análise de Sementes, no período de janeiro a agosto de 1996

3 Comportamento dos vinte lotes de milho híbrido AG- 510, em relação à emissão de raiz primária da semente, quando submetidas ao teste de precocidade de emergência da raiz primária a 30,25 e $20^{\circ} \mathrm{C}$ de tempertura respectivamente

4 Emissão da raiz primária das sementes de milho híbrido AG510 , durante os períodos de exposição nos germinadores à 30,25 e $20^{\circ} \mathrm{C}$ (média dos vinte lotes nas três épocas)

\section{TABELAS DO APÊNDICE}

$1 \mathrm{~A}$ Valores médios da precipitação pluvial ( $\mathrm{mm}$ ) e temperaturas $\left({ }^{\circ} \mathrm{C}\right)$ máximas e mínimas semanais. Período de agosto de 1995 a julho de 1996. (Dados fornecidos no Departamento de Física e Meteorologia da ESALQ. Piracicaba, SP.)

2A Valores médios da umidade relativa do ar (\%) e temperaturas $\left({ }^{\circ} \mathrm{C}\right)$ média, máxima e mínima por decêndio. Período de janeiro a agosto de 1996. (Dados obtidos no LAS do Departamento de Agricultura da ESAQ. Piracicaba, SP.).........

3A Número de sementes com emissão de raiz primária durante os periodos de exposição no germinador a 20,25 e $30^{\circ} \mathrm{C}$, dos vinte lotes de milho híbrido AG- 510. Piracicaba, SP., 1996..... 


\title{
AVALIAÇÃO DO VIGOR DE SEMENTES DE MILHO (Zea mays L.) PELA PRECOCIDADE DE EMISSÃO DA RAIZ PRIMÁRIA.
}

\author{
Autor: José Hilario Hernández Salgado \\ Orientador: Prof. Dr. Francisco Ferraz de Toledo
}

\section{RESUMO}

Com a finalidade de se estudar a variação do desenvolvimento radicular inicial em sementes de milho (Zea mays L.) foram estimados índices de precocidade de emissão da raiz primária (PER), nas temperaturas de 20, 25 e $30^{\circ} \mathrm{C}$, como parâmetros para se determinar a qualidade fisiológica de lotes destinados à comercialização. Esses índices foram comparados com métodos tradicionais de laboratório para avaliação de vigor e com a emergência de plântulas no campo a fim de verificar o grau de correlação entre os mesmos.

Para a pesquisa utilizou-se amostras de vinte lotes, sem tratamento fungicida, do híbrido AG-510, produzidas na safra 94/95, pela Empresa Agroceres, unidade de Santa Cruz das Palmeiras, no estado de São Paulo. Os ensaios foram realizados no Departamento de Agricultura da Escola Superior de Agricultura "Luiz de Queiroz", em Piracicaba, SP., durante três épocas: janeiro, abril e julho de 1996.

A análise estatística e a interpretação dos resultados revelaram que 0 novo teste PER, a 20 e $25^{\circ} \mathrm{C}$, mostrou-se satisfatório, nas três épocas em que foi empregado, para classificar com regularidade os diferentes materiais utilizados na pesquisa. Evidenciou, também, uma correlação altamente significativa com os testes mais usados para se determinar a qualidade de sementes de milho, como o teste de frio e o de condutividade elétrica. Já 0 teste PER $-30^{\circ} \mathrm{C}$ não apresentou as mesmas virtudes. 
Com base nesses resultados concluiu-se que a precocidade de emissão da raiz primária, à 20 e $25^{\circ} \mathrm{C}$, pode ser de grande utilidade para avaliação de vigor de sementes de milho. 


\title{
EVALUATION OF SEED VIGOR OF CORN (Zea mays L.) BY THE PRECOCITY OF THE PRIMARY ROOT EMISSION
}

\author{
Author: José Hilario Hernández Salgado \\ Adviser: Prof. Dr. Francisco Ferraz de Toledo
}

\section{SUMMARY}

The objetive of this study was to evaluate variations in the emergence of seed radicles of corn (Zea mays L.), under different temperatures $(20,25$ and $30^{\circ} \mathrm{C}$ ), and to establish indexes of the primary root emissão (PER) to test the vigor of commercial seed lots. The indexes were compared to traditional laboratory and field methods of testing for physiological fitness of seeds.

For this research samples of corn seeds (not treated with fungicide) were taken from twenty different lots of the hybrid AG- 510 produced in the 94/95 growing season by Agroceres (Santa Cruz das Palmeiras, SP. Brazil). The experiments were conducted during January, April and July of 1996 in the Department of Agriculture at the School of Agriculture "Luiz de Queiroz" University of São Paulo, Piracicaba, SP. Brazil.

Statistical analysis and interpretation showed that the results obtained using the PER at 20 and $25^{\circ} \mathrm{C}$ were consistent and reproducible. Furthermore, this research showed a significant correlation to other tests used to determine seed quality, such as the cold test and the eletrical condutivity test. Emission of the Primary Root (PER) at $30^{\circ} \mathrm{C}$ was representative, but could not be correlated with important seed quality tests.

Based upon these results, we conclude that the Primary Root Emission at 20 e $25^{\circ} \mathrm{C}$ can be of great value in evaluating the vigor of corn seeds. 


\section{INTRODUÇÃO}

Com o advento do milho híbrido, a agricultura moderna teve grande impulso e mostrou predisposição para absorver tecnologia de ponta. Deste contexto fazem parte as sementes de alta qualidade, que envolve aspectos relacionados com a pureza genética, a pureza física, a fisiologia e a sanidade, salientando-se que constituem o insumo mais seguro e econômico do processo de produção de muitas espécies.

No Brasil, as empresas particulares cultivam aproximadamente $85 \mathrm{mil}$ hectares de campos de sementes dessa graminea, desde o Rio Grande do Sul até o Cerrado Brasileiro, visando um mercado que movimenta ao redor de 235 milhões de reais por ano (Souza,1995). A competição entre essas empresas e as exigências dos agricultores, que operam sob condições ambientais as mais diversas, vêm se tornando cada vez mais evidentes.

Para a avaliação da qualidade fisiológica dos lotes destinados à comercialização, tem sido o poder germinativo determinado através do teste padrão de germinação. Este envolve procedimentos padronizados que possibilitam a obtenção de resultados uniformes entre diferentes analistas e laboratórios, mas propiciam condições ótimas às sementes. Apesar de ser um método muito importante e indispensável, é restrito porque não é capaz de estimar o desempenho dos materiais no campo e no armazenamento, onde as circunstâncias podem variar desde ótimas às extremamente adversas. Com isso, nas últimas décadas, as instituições de pesquisa e as empresas de sementes tem usado os testes de vigor para melhor julgar os lotes. Porém, ainda não se tem resultados consistentes que permitam estabelecer métodos padronizados 
para culturas de grande importância econômica, como é o caso do milho; além disso, em geral, são complexos e pouco práticos.

Assim, considerando o teste padrão de germinação como um dos poucos processos com reconhecimento e de emprego em nivel internacional, acredita-se que seja interessante estudar detalhes do mesmo, com o objetivo de se explorar a possivel variação da emissão radicular a fim de se avaliar o vigor dos lotes de sementes.

Portanto, o presente trabalho teve por finalidade estudar a precocidade de emissão da raiz primária de sementes de milho (Zea mays L. ), em comparação com outros parâmetros obtidos de testes de germinação e de vigor, visando a sua utilização nos laboratórios de análise de sementes. 


\section{REVISÃO DE LITERATURA}

\section{1. Água e o processo da germinação}

Segundo Kermode et al. (1986) a embebição de água, na semente madura viável e não dormente, promove uma reativação dos sistemas metabólicos existentes, suplementada pela síntese de novos componentes, que conduzem à expansão e à divisão celulares enquanto a plântula se estabelece. Assim, mudanças quantitativas e qualitativas em enzimas catabólicas, particularmente nos órgãos de reserva (endosperma, perisperma e cotilédones), são eventos comumente observados.

Durante o processo de germinação, a absorção de água ocorre em duas fases, uma de expressiva embebição, sendo aparentemente um processo físico e a outra de aparente repouso, com o crescimento da radícula (Hegarty, 1977).

Por outro lado, Bewley \& Black (1985) descreveram o processo de germinação em três fases distintas ou padrão trifásico, onde a terceira (última) fase é caracterizada pelo crescimento visivel do eixo embrionário, sendo associada a significativos incrementos da taxa de absorção de água e de atividade respiratória. A ruptura dos tegumentos ou coberturas da semente pode ser resultante da pressão exercida pelo aumento do volume do embrião através do crescimento do seu eixo. Assim, a extensão e a divisão celular causarão a elongação da raiz primária (Berlyn, 1972). A sincronia entre a divisão e a elongação tem sido observada em aveia, tomate e em alface a $26^{\circ} \mathrm{C}$ (Hegarty, 1978). Haber \& Luippold (1960), todavia, relataram que a divisão e a elongação celulares não são necessariamente sincronizadas, podendo ser 
descompensadas pela ação de temperaturas baixas $\left(10^{\circ} \mathrm{C}\right)$ retardando a mitose ou por estresse hídrico (- 9,9 a - 12,8 atm). A protusão da radícula pode ser devida à elongação celular combinada com a divisão mitótica ou unicamente à elongação. Bauer \& Black (1983) observaram que há casos em que o crescimento das raízes e do coleóptilo são evidentes; há outros em que as modificações das estruturas embrionárias não são aparentes, porém os processos iniciais de ativação metabólica estão ocorrendo e, nestes casos, o coleóptilo e as raizes apresentam algum desenvolvimento, mas encontram-se imersos no pericarpo. A detecção da germinação pode, então, exigir o exame detalhado das sementes. Neste sentido, Simmons (1987) e Silva (1989) indicaram que a entrada de água é promovida fundamentalmente pela radícula que, geralmente, é emitida antes da parte aérea.

Segundo Gulliver \& Heydecker (1973), a abundante disponibilidade de água propicia à semente maior velocidade de embebição. Neste caso, sob condições aeróbicas, a emergência da radícula ocorre precocemente em teor de água mais elevado. Sementes de envilha (Pisum sativum), entretanto, tiveram menor média de germinação quando a tensão de água foi de $0 \mathrm{~atm}$, ou seja, a $100 \%$ de capacidade de campo. A esse respeito, Nijenstein (1985) indicou que condições anaeróbicas, por excesso de água, são prejudiciais à semente, com conseqüente carência de oxigênio, retardamento do desenvolvimento radicular (Grable \& Danielson, 1965), redução da taxa de emergência (Peske \& Delouche, 1985) e elevação da incidência de microorganismos nas sementes em germinação (Norton, 1986). Para estudar o efeito de emergência de radícula ou germinação fisiológica em dois cultivares de sorgo, Korocolo (tolerante ao estresse) e Ariana (susceptivel), Gurmu \& Naylor (1991) testaram o tratamento de 0 atm e PEG., obtendo o seguinte resultado: a - $1.15 \mathrm{Mpa}$ não emergeriram os coleóptilos nem a radícula de Ariana, mas Korocolo manteve a germinação acima de $40 \%$. 
Chastain et al. (1995), ao avaliar sistemas de conservação de solo onde se produz trigo, mostraram que o desempenho das técnicas foi influenciado pelo potencial genético, tamanho e qualidade da semente. $A$ emergência entre cultivares foi influenciada pelo crescimento do coleóptilo, mas o crescimento deste não foi relacionado com o tamanho da semente.

Sung \& Chang (1993) estudaram os tratamentos de hidratação e precondicionamento com polietileno-glicol (PEG-6000), o qual é usado para melhorar a taxa e uniformidade da germinação de sementes. Neste, $50 \mathrm{~g}$ de sementes de milho foram misturadas com $100 \mathrm{~g}$ de vermiculita número 3 , sendo logo adicionados $125 \mathrm{ml}$ de água destilada, colocadas em caixas de plástico e levadas ao germinador por 24 horas a $25^{\circ} \mathrm{C}$. Ambos tratamentos melhoraram a porcentagem, o tempo médio e uniformidade de emergência, especialmente sob temperaturas subótimas $\left(10\right.$ e $\left.15^{\circ} \mathrm{C}\right)$; o resultado observado foi atribuído ao condicionamento induzido que proporcionaria mudanças no conteúdo bioquímico das sementes (pela ação da enzima alfa-amilase nas primeiras etapas da germinação) além da melhoria da integridade das membranas assim como aumento nas atividades fisiológicas da germinação.

\subsection{Temperatura e o processo da germinação.}

Em termos gerais, as sementes de diferentes espécies e cultivares tem um comportamento variável no que se refere à temperatura ótima para o crescimento do embrião e plântula. Metiever (1979) define como temperatura ótima aquela em que ocorre a maior porcentagem de germinação em um menor espaço de tempo. Neste sentido, Ferreira et al. (1990) mencionaram que a temperatura para a germinação das sementes tem grande influência não só sobre a velocidade do processo como na porcentagem de germinação. Assim, 
ao colocar sementes a germinar, quanto mais baixa é a temperatura maior é a quantidade de oxigênio disponivel ao embrião porque o metabolismo respiratório é incipiente e mais lenta será a germinação. Em temperaturas elevadas, porém, menor será a quantidade de oxigênio disponível ao embrião, uma vez que o metabolismo respiratório aumenta ( Côme \& Tissaoui, 1973).

Em estudos sobre o efeito da temperatura na emergência de plântulas de soja, Matthews \& Hayes (1982) observaram que o tempo necessário para obter $50 \%$ de emergência foi de 8 dias a $13^{\circ} \mathrm{C}$; a maior diferença entre os cultivares foi observada a $7,5^{\circ} \mathrm{C}$. No caso de milho, Hope \& Maari (1994) obtiveram diferenças médias de 3.8 a 22 dias para a produção de $1 \mathrm{~cm}$ de coleóptilo às temperaturas de 25 e $11^{\circ} \mathrm{C}$ respectivamente. Kamaha \& Maguire (1992) verificaram em sementes de trigo, que temperaturas inferiores a $17^{\circ} \mathrm{C}$ provocaram queda considerável nos processos biológicos da germinação, enquanto que a $20^{\circ} \mathrm{C}$ este cereal mostrou boa resposta a emergência de plântulas.

As Regras para Análise de Sementes (Brasil, 1992) prescrevem para os testes de germinação com milho, as temperaturas de $20-30^{\circ} \mathrm{C}$ alternadas ou $25,30,20^{\circ} \mathrm{C}$ constantes; a variação da temperatura, a cada 24 horas, não deve ser superior $\mathrm{a} \pm 1^{\circ} \mathrm{C}$.

A água é um fator determinante sobre o processo de germinação (Carvalho \& Nakagawa, 1988), devendo se encontrar disponível para as sementes em quantidade adequada. Em relação ao umedecimento do substrato, as Regras para Análise de Sementes (Brasil, 1992) recomendam para o substrato de areia $50 \%$ da capacidade de retenção para as sementes de gramíneas em geral e de $60 \%$ para leguminosas e milho. 


\subsection{Avaliação da qualidade fisiológica}

\subsubsection{Teste padrão de germinação (TPG)}

De acordo com as Regras para Análise de Sementes (Brasil, 1992), considera-se germinada toda a semente que, pela emergência e desenvolvimento das estruturas essenciais do seu embrião, demonstre aptidão para produzir planta normal sob condições favoráveis de campo.

Em nivel de laboratório, O TPG é conduzido sob as condições consideradas ótimas para as espécies. Sem dúvida, isto cria a oportunidade para que plântulas débeis possam desenvolver-se ao ponto de serem consideradas normais (Popinigis, 1977). Além disso, não distingue amostras com germinação rápida e lenta (Marcos Filho et al., 1987). Então, segundo Delouche (1963) e Vaughan (1971), uma alta porcentagem de germinação não significa, necessariamente, que o lote venha a ter emergência satisfatória sob condições de campo, porque essas condições ideais nem sempre se acham presentes, quando os agricultores estão realizando suas semeaduras. Mas quando as condições de campo são favoráveis, os resultados do TPG apresentam alta correlação com a emergência no campo (Carvalho \& Nakagawa, 1988). Porém para condições desfavoráveis será necessário usar testes de vigor para estimar o ordenamento dos lotes na emergência em campo (Bekendam et al., 1987).

Apesar de reconhecer as deficiências dos testes de germinação, Delouche (1981) alega que eles não devem ser eliminados, pois ainda são a melhor maneira para se avaliar a qualidade das sementes, por envolverem procedimentos padronizados, cujos resultados são reproduziveis dentro e entre 
laboratórios. Por outro lado, o ensaio de emergência, que emprega areia para substrato, também é utilizado como teste de germinação (Popinigis, 1977).

\subsubsection{Primeira contagem de germinação}

No processo de deterioração, segundo McDonald (1975) e Matthews (1985), a velocidade decai antes que a porcentagem de germinação e, portanto, as amostras que se desenvolvem com maior rapidez apresentam valores mais elevados na primeira contagem. Estas, conforme a literatura, podem ser consideradas mais vigorosas do que aquelas que crescem lentamente. Como se sabe, o teste da primeira contagem é conduzido em conjunto com o de germinação, e, para milho a avaliação é procedida 4 dias depois da semeadura (Marcos Filho et al., 1985).

De acordo com a AOSA (1983), esse teste apresenta algumas vantagens importantes, pois é barato, relativamente rápido, não requer equipamentos adicionais nem treinamento tecnológico especial; mas, tem sido criticado devido as variáveis, como umidade e temperatura, que dificilmente são padronizadas entre laboratórios e exercem influência sobre a velocidade de germinação, assim como ao analista que deve ter um conceito bem definido sobre uma semente germinada. Fratin (1987) afirmou que este teste foi capaz de diferenciar qualidade entre lotes, relacionando-o com a emergência de plântulas em campo.

Quando a porcentagem de germinação é alta e similar, em diferentes lotes, tornam-se de grande utilidade os testes de vigor (Ellis \& Roberts, 1980), porque eles visam a identificação de possiveis diferenças 
significativas na qualidade fisiológica entre lotes com distintos desempenhos após a semeadura elou durante o armazenamento (Marcos Filho, 1994). Conforme Perry (1980) a validade dos testes de vigor depende de sua associação com algum fator do comportamento dos lotes como, por exemplo emergência. Assim, sempre que seja possivel, estes ensaios devem ser relacionados à emergência em campo, em vista de ser esta a situação prática para a qual o teste fornecerá informação (Matthews, 1981; Perry, 1984).

\subsubsection{Teste de frio}

Sementes de milho são rotineiramente avaliadas através do teste de frio, no qual condições adversas de campo são simuladas no laboratório, sendo este método, de estresse fisiológico, amplamente usado por empresas produtoras de sementes em programas internos de controle de qualidade (Tekrony, 1983; Nijenstein, 1988).

É realizado em laboratório, sob condiçōes controladas, com o objetivo de selecionar lotes de boa qualidade cujas sementes germinem bem em uma ampla faixa de condições de temperatura e umidade do solo (Cícero \& Vieira, 1994). Além disso, é importante lembrar que baixa temperatura e excesso de água no solo podem reduzir a velocidade de emergência das plântulas e favorecer 0 desenvolvimento de microorganismos patogênicos como Phytium spp. e Giberella zeae. O teste de frio é, também, considerado próprio para se avaliar a eficiência de tratamento fungicida em sementes (Cícero et al., 1989).

Com o propósito de avaliar a influência do teor de água do substrato sobre a porcentagem de plântulas normais de 10 lotes de milho, no teste de frio, Nijenstein (1988) estudou vários níveis de capacidade de campo, 
entre 34 e $78 \%$. Obteve uma interação significativa entre lotes e o teor de água do substrato. A $34 \%$ os lotes de baixo vigor germinaram rapidamente, mas quando foram expostos a $61 \%$, de capacidade de campo, tiveram os mais baixos valores de germinação em relação aos lotes de alto vigor; concluiu que a definição de estratos ou níveis dos lotes no teste de frio é predominantemente influenciada pela qualidade da semente.

Temperaturas de 5 a $10^{\circ} \mathrm{C}$ podem induzir a desnaturação das proteínas das membranas celulares, provocando injúrias que afetam o processo de germinação. Essas injúrias podem ser: lesões estruturais no meristema radicular, proliferação de raízes seminais, atraso no crescimento das plântulas e redução na sobrevivência (Burris \& Navratil, 1979). Segundo Mock \& Eberhart (1972) há sistemas genéticos que condicionam a tolerância ao frio nas populações de milho e que são independentes daqueles que controlam a emergência e a maturidade em condições normais de plantio.

$\mathrm{Na}$ semeadura sob condições de baixas temperaturas e baixos teores de água da semente, há uma relação positiva entre a quantidade de metabólitos perdidos e mortalidade anterior à emergência (Wolk \& Herner, 1982); portanto, quanto mais baixa a qualidade das sementes, maior a exsudação de solutos durante a embebição e maior 0 estimulo ao desenvolvimento de estruturas de fungos no solo (Harman, 1983).

Abdul - Baki (1980) relatou, de experimentos conduzidos por Wilson \& Crawford, resultados indicando que apenas uma porção dos lipídeos das membranas precisa ser alterada para induzir resistência das sementes ao frio. Entretanto, a utilização de solo com variações em suas características físicas, químicas e de microflora constitui o principal entrave à padronização; porém, Burris \& Navratil (1979), estudando procedimentos empregados por diversos laboratórios na condução do teste de frio com sementes de milho, constataram que a menor variação para o método foi obtida com a utilização 
de rolos de papel com uma pequena quantidade de solo. Mais tarde, porém, Loeffler et al. (1985) sugeriram a eliminação do solo do teste para minimizar ainda mais a variabilidade dos resultados. $\mathrm{Na}$ atualidade é uma metodologia alternativa de maior simplicidade e com vantagens para padronizar-se.

Grabe (1968) observou que, com o uso do teste de frio, os lotes de boa qualidade devem apresentar no mínimo de 70 a $85 \%$ de plântulas normais.

Quanto à correlação do teste de frio com emergência de plântulas em campo tem-se feito algumas pesquisas em diversos locais dos USA e Europa em solos frios e úmidos; a respeito, Martin et al. (1988) avaliaram 48 linhas de milho em 9 localidades de solos frios e úmidos e sua relação com testes de laboratório (teste de frio e teste de embebição em etanol). Os resultados indicaram que no ano de 1986, os testes de laboratório foram igualmente correlacionados com emergência de campo, $r=0,43^{\star *}$ e $r=0,40^{\star *}$, respectivamente, e em 1987 o teste de frio foi mais correlacionado com emergência de campo $\left(r=0,74^{\star *}\right)$ do que os testes de embebição e de etanol ( $\left.r=0,43^{\star \star}\right)$. Concluíram que essas correlações entre testes de laboratório e emergência de campo foram afetadas pela localidade e pelo ano. Por outro lado, Bruggink et al. (1991) avaliaram sementes de milho sem e com tratamento fungicida por meio do teste de frio e compararam com o de germinação. Os resultados indicaram que o melhor tratamento para a caracterização dos lotes foi o teste de frio sem tratamento fungicida $(r=0.92)$. Uma resposta similar foi obtida para sementes de beterraba em teste de frio em areia (Lovato \& Cagalli, 1992). Não obstante, Perry (1981) indicou que o teste de frio apresentou resposta similar ao envelhecimento artificial, à germinação e à emergência de plântulas no campo em lotes de milho. 


\subsubsection{Teste de envelhecimento precoce}

É um teste de estresse fisiológico onde as sementes são submetidas a um ambiente com alta temperatura e elevada umidade relativa do ar, o que causa deterioração. Segundo Delouche (1965) este teste ganhou popularidade na industria de sementes em decorrência de três qualidades, a saber: 1) é simples e de fácil execução, requerendo como equipamento adicional somente uma câmara de envelhecimento; 2) a interpretação dos resultados é feita segundo critérios do TPG; 3) é rápido, porque precisa só de alguns dias a mais do que o teste de germinação (McDonald Jr., 1975). Além disso, Popinigis (1977) e Tekrony \& Egli (1977) o consideram como prático e regularmente satisfatório para a avaliação de diferenças de vigor entre lotes e é aplicável a uma gama muito grande de espécies.

A suposição básica para o desenvolvimento da metodologia descrita por Delouche \& Baskin (1973) foi o processo da deterioração das sementes sob condições normais. Assim, sementes colocadas em altas temperaturas $\left(40\right.$ a $\left.45^{\circ} \mathrm{C}\right)$ e alta umidade relativa do ar $(100 \%)$, por um periodo de tempo pré-establecido, teriam rápido declínio na germinação, o qual seria relacionado com a aceleração da deterioração, isto é, lotes de alto vigor decairão relativamente pouco, enquanto que os de baixo vigor mostrarão uma marcada queda de germinação devido ao efeito das mudanças na integridade das membranas ( Basavarajappa et al. 1991).

Além da temperatura e umidade relativa do ar a que são expostas as sementes, Delouche (1976) inclui entre as principais variáveis, o tempo de exposição e a qualidade do material a ser testado. Outras mudanças que podem afetar significativamente os resultados, são: tamanho e número de amostras na câmara, teor inicial de água da semente, condições de 
germinação após o período de envelhecimento e o critério usado na interpretação dos testes.

No milho, o período de exposição das sementes às condições de envelhecimento variam entre 96 e 120 horas, conforme o cultivar (Tao, 1980).No caso da pesquisa feita por Fratin (1987) o período de 96 horas foi suficiente para revelar variações de vigor. Por sua vez Dias \& Barros (1995) incluem nesse procedimento um período de 72 horas para avaliação de lotes de milho.

Basavarajappa et al. (1991) afirmam que a diminuição de fosfolipídios, a redução dos carboidratos, açúcares e proteínas solúveis, o aumento do total de ácidos graxos livres e a maior sensibilidade ao efeito do oxigênio e radicais livres são as causas da peroxidação lipídica das membranas das células. Em vista deste fato, o conteúdo do malonaldeido aumenta (o qual é um produto da peroxidação lipídica) e incrementa a deterioração das sementes, particularmente no fim de 96 horas. No caso da soja, Parrish \& Leopold (1978) sugeriram que as mudanças por envelhecimento ocorrem via peroxidação, incluindo os ácidos graxos insaturados. Francis \& Coolbear (1988) reportaram, em sementes de tomate, a acumulação de ácido esteárico (um ácido graxo saturado) e um decréscimo de ácidos graxos insaturados por efeito do tratamento de envelhecimento acelerado.

Em relação a temperatura utilizada neste teste, recomenda-se, para as sementes pequenas de Trifolium pratense, $40^{\circ} \mathrm{C}$ (Wang et al., 1994) e de $45^{\circ} \mathrm{C}$ para feijão comum e feijão mungo (Hampton et al., 1992). No milho, tem-se utilizado $42^{\circ} \mathrm{C}$, admitindo-se variação de $\pm 1^{\circ} \mathrm{C}$ (Basavarajappa et al., 1992; Dias \& Barros, 1995). 
Com referência ao teor da água, as pesquisas feitas indicam que as sementes mais úmidas, em geral, são mais sensiveis às condições do teste, sendo conveniente a sua uniformização. É recomendável que apresentem de $11-13 \%$ de água ao serem submetidas ao teste.

$\mathrm{Na}$ atualidade, emprega-se com freqüência o tratamento com fungicidas, durante o beneficiamento de sementes como prevenção contra patógenos; então, para se constatar seu efeito sobre o potencial fisiológico das amostras avaliadas pelo teste de envelhecimento, tem-se realizado algumas pesquisas como na soja (Marcos Filho \& Shioga, 1981), feijão (Alizaga et al., 1990), beterraba (Lovato \& Cagalli, 1992) e sorgo (Shekaramúrthy et al., 1994). Vem sendo observado que as sementes tratadas apresentam porcentagens mais altas de germinação após o envelhecimento.

Apesar das qualidades do teste, não se tem conseguido a reprodutibilidade dos resultados dentro e entre laboratórios, sendo necessária a rigorosa padronização para que seus efeitos possam ser comparados; portanto, constitui ela prioridade nas considerações de vários pesquisadores (Popinigs, 1977; McDonald \& Phaneendranath, 1978; Tao, 1979) .

McDonald \& Phaneendranath (1978) testaram dispositivos alternativos para serem utilizados como câmaras de envelhecimento para sementes de soja, sendo o método do "gerbox" considerado o melhor para diferenciar niveis de vigor, além de mais versátil e fácil de padronizar, pelas seguintes razões: é de baixo custo e usa materiais normalmente encontrados em laboratórios; as sementes são distribuídas em uma só camada, ficando uniformemente expostas às condições ambientais e é relativamente rápido. Fratin (1987) observou, em seu trabalho, que um dos fatores que contribuiu para 0 acréscimo de uniformidade, entre os resultados obtidos, foi 0 uso do método do "gerbox". 
Sobre a quantidade de água usada, Tao (1979) relatou que quando foram utilizados $80 \mathrm{ml}$, ao se movimentar o "gerbox", facilmente se umedecia as sementes, o que não ocorria quando usou $40 \mathrm{ml}$. Resultados preliminares de quatro laboratórios que empregaram $40 \mathrm{ml}$ de água, em sementes de soja, foram similares.

Tomes et al. (1988) verificaram que o número de caixas por prateleira e o posicionamento desta na incubadora têm influência sobre a temperatura interna das caixas.

As correlações entre o envelhecimento acelerado e a emergência de campo, em Cicer arietinum L., foram positivas e altamente significativas; assim esse teste pode ser usado para indicar a emergência de campo da espécie (Ram et al., 1989).

\subsubsection{Teste de condutividade elétrica}

O teste de condutividade elétrica tem sido internacionalmente aceito como um indicador de vigor para ervilha (Pisum sativum L.). Baseia-se no princípio de que sementes de baixo vigor, quando imersas em água, liberam maiores quantidades de eletrólitos do que as vigorosas, devido ‘a perda da integridade das membranas celulares (Matthews \& Powell, 1981; Hampton \& Coolbear, 1990). Portanto, as análises de exsudatos de sementes para açúcares solúveis, aminoácidos e eletrólitos tem sido usadas para avaliar a qualidade das sementes (Takayanagi \& Murakami, 1968; Matthews \& 
do material em água por um certo período e os solutos liberados possuem cargas elétricas que podem ser medidas com um condutívimetro ( Loeffler et al., 1988). Assim o valor da condutividade é função da quantidade de exsudatos na solução (Khan, 1982; Dadlani \& Agrawal, 1983; Simon, 1984). A pesquisa tem, ainda, demostrado que outros fatores podem afetar os resultados do teste, tais como: grau de desenvolvimento da semente no momento da colheita, a deterioração e o dano pela embebição (Powell, 1986), qualidade da água, conteúdo de íons da água da solução, temperatura e duração do período de embebição e número de sementes testadas ( Hampton et al., 1992).

Ao se realizar o teste de condutividade dentro de um sistema de controle de qualidade, a avaliação é feita em uma subamostra, com o propósito de representar o lote a ser testado. Então, a respeito, Loeffler et al. (1988) sugeriram a realização do teste com sementes puras, sendo justificável o uso de amostra maior para diluir os efeitos de sementes danificadas, já que estas podem causar aumentos significativos na condutividade elétrica do lote (Tao, 1978). Em trabalhos de pesquisa onde se tem objetivos específicos, a escolha das sementes sem qualquer tipo de injurias é fundamental (Tao, 1980; AOSA, 1983; Marcos Filho et al., 1987). Vieira (1994) também recomendou sementes selecionadas em estudos dessa natureza, dando preferência para o material colhido e trilhado manualmente.

Em sementes grandes como as de evilha (Matthews \& Bradnock, 1968), milho (Lin, 1988; Herter \& Burris, 1989) e soja (Tao, 1978; AOSA,1983; Loeffler et al., 1988) o tempo de embebição, que permite mostrar diferenças entre lotes, é de $24 \mathrm{~h}$. É, porém, possivel ter reduções nesse tempo quando se tem acréscimos de temperatura acima de $25^{\circ} \mathrm{C}$ (Murphy \& Noland, 1982; Loeffler et al., 1988), quando a diferença de vigor entre lotes é grande (Marcos Filho et al., 1990) e quando existe variação na permeabilidade de tegumento 
entre genótipos (Costa et al., 1984; Kuo, 1989). Em soja, Edje \& Burris (1970) destinguiram diferenças nos níveis de qualidade usando períodos de embebição de 12 horas. Para o caso do milho, Bruggink et al. (1992) verificaram, em sementes envelhecidas artificialmente, a liberação de solutos após 10 horas de embebição.

Sementes de soja com teores de água entre 11 e $19 \%$ revelaram valores semelhantes de condutividade (Tao, 1978; Loeffler et al., 1988). Quando se avaliou lotes com grau de umidade inicial inferior a $11 \%$, houve aumento da condutividade. Similarmente, Hampton et al. (1992) observaram acréscimos na condutividade eléctrica em sementes de feijão mungo e soja com teores de água inferiores a $10 \%$. É, pois, importante salientar que as amostras de soja são recebidas nos laboratórios com teor de água que varia usualmente entre $8-15 \%$, dando origem a problemas para as avaliaçōes. Alguns autores recomendaram a uniformização do teor de água em sementes dessa espécie entre 11 e 17\% (AOSA, 1983).

Outras variáveis envolvidas no teste de condutividade são: uso de água deionizada, com no máximo de 2 a 3 micromhos $/ \mathrm{cm}$, recipiente de $125 \mathrm{ml}$ (para que 0 volume da água seja suficiente para cobrir as sementes) e 0 número de 4 repetições por lote, conforme indicações da AOSA e da ISTA (Loeffler et al., 1988; Hampton et al., 1992).

Fratin (1987), utilizando o teste de condutividade elétrica em sementes de milho, verificou que tratava-se de um método que fornece resultados parcialmente consistentes, porém, promissor para a avaliação de lotes dessa gramínea.

A avaliação da condutividade individual é feita através de um analisador automático eletrônico, tal como ○ ASA-610 e o ASAC-1000 
(McDonald Jr. \& Wilson, 1979, 1980; Steere et al., 1981; Wann, 1986; Wilson \& Trawaltha, 1991; Tyagi, 1992). Estes aparelhos medem a quantidade de exsudatos que são liberados por 100 sementes individuais em rápida sucessão (Wilson Jr., 1992).

Este método foi usado para selecionar um valor limite que seja capaz de distinguir sementes viáveis das não viáveis. Foi estabelecida a medida de partição de sementes germináveis e não germináveis em $90 \mu \mathrm{A}$, conforme recomendações dos fabricantes, tanto para o ASA-610 (McDonald Jr. \& Wilson, 1980) como para o analisador ASAC-1000 (Tyagi, 1992). A este respeito, Matthews (1981) destacou que, na análise de rotina, a divisão comum poderá ser aplicável a todos os lotes de uma espécie. Por exemplo, para soja Krzyzanowski \& Miranda (1990) indicaram $50 \mu$ A como ponto de partição.

Herter \& Burris (1989) avaliando a condutividade elétrica individual de sementes de milho e relacionando-a com a germinação e crescimento de plântulas, revelaram que as de baixa qualidade responderam melhor que aquelas de alta ou intermediária. Por tanto, o método pode ser útil para o descarte de lotes inferiores. Entretanto, Deswal \& Sheoram (1993), relataram que em sementes pequenas o exsudato de eletrólitos é relativamente menor sendo, então, um problema a medição do limite de partição pela condutividade elétrica. Uma forma de se solucionar esse problema é calcular o peso de 100 sementes antes de listá-las, para possibilitar a apresentação de resultados médios em micro amperes/g $(\mu \mathrm{A} / \mathrm{g})$ de acordo com Vieira (1994).

Verificou-se que a maior parte das pesquisas sobre 0 teste de condutividade elétrica abrange sementes de leguminosas, como ervilha e soja, as quais servem de base para estudos em outras espécies, como o caso do milho. Apesar do amplo interesse pelo teste de condutividade elétrica individual 
poucos trabalhos tem sido conduzidos visando o seu uso na rotina dos laboratórios.

Em ervilha, Bedford (1974) constatou a eficiência do teste de condutividade elétrica em relação à emergência das plântulas entre lotes semeados no campo. Em soja, Oliveira et al. (1984), ao avaliarem 18 lotes de sementes, observaram leituras de condutividade altamente correlacionadas com emergência, na primeira $(r=-0,89 * k)$ e na segunda semeaduras $(r=-$ $\left.0,92^{\star \star \star}\right)$, sendo a condutividade elétrica o melhor indicador da emergência de campo do que o teste de germinação. Fernandez \& Johnston (1992), trabalhando com sementes de lentilha, feijão vagem e grão-de-bico, verificaram que a condutividade elétrica foi 0 teste que melhor se correlacionou com emergência. Testes desse tipo em milho-doce também mostraram relação com a emergência de campo (Waters Jr. \& Blanchette, 1983; Tracy \& Juick, 1988 Wilson \& Trawatha, 1991; Parera et al., 1995).

\subsubsection{Testes combinados}

Num esforço para desenvolver índices mais exatos de vigor em milho, tem-se pesquisado testes que envolvem avaliações baseadas em mais de uma técnica e o detalhamento da informação provida pelos procedimentos usados. Barla-Szabó \& Dolinka (1988), ao compararem o teste de vigor de estresse complexo (CSTV) com alguns métodos tradicionais, como o teste de frio, envelhecimento artificial e o teste de condutividade elétrica (ASA-610), obtiveram resultados que apresentaram maior relação com a emergência no campo que com os métodos tradicionais indicados. Styler \& Cantliffe (1983) utilizando 13 híbridos de milho doce evidenciaram que testes múltiplos tiveram correlação negativa $\left(r=-0,58^{* *}\right)$ com a condutividade e a emergência de 
campo, enquanto que emergência em campo e o teste de germinação não foram significativamente correlacionados $(r=-0.18)$. Já a combinação dos resultados dos testes de envelhecimento artificial e condutividade individual (ASA-610), foi eficiente para estimar o estado fisiológico de sementes de milho (Wilson \& Trawatha, 1991; Wilson Jr., 1992). 


\section{MATERIAL E MÉTODOS}

\subsection{Localização}

O presente trabalho foi conduzido durante os anos de 1995 e 1996, utilizando-se as instalações do Laboratório de Análise de Sementes (LAS) e do Campo Experimental (CE) do Departamento de Agricultura, da Escola Superior de Agricultura "Luiz de Queiroz, em Piracicaba, São Paulo, Brasil, situada a $22^{\circ}$ $42^{\prime}$ de latitude sul, $47^{\circ} 48^{\prime}$ de longitude oeste e $580 \mathrm{~m}$ de altitude, com temperatura mínima média de $14,3^{\circ} \mathrm{C}$, máxima média de $27,8^{\circ} \mathrm{C}$ e média de $23,8^{\circ} \mathrm{C}$ e precipitação pluvial média anual de $1.257 \mathrm{~mm}$ (Ometto, 1991).

\subsection{Lotes de sementes}

Foram utilizados nesta pesquisa vinte lotes de sementes de milho híbrido AG-510 (peneira 23), colhidos e beneficiados em 1995, pela Empresa Agroceres, unidade de Santa Cruz das Palmeiras, no estado de São Paulo.

Esse material, recebido no LAS no mês de agosto de 1995, que já havia sofrido tratamento com inseticida, foi armazenado em câmara com umidade relativa do ar de $48 \%$ e temperatura de $20^{\circ} \mathrm{C}$. Em dezembro de 1995, cada um dos lotes foi homogeneizado e dividido em três amostras com $2 \mathrm{~kg}$ que, embaladas em sacos de papel "kraft" etiquetados, retornaram ao mesmo local de conservação. As amostras (uma de cada lote por época) foram utilizadas 
para a retirada de subamostras destinadas à instalação dos testes que se acham descritos nos itens que vêm a seguir.

\subsection{Precocidade da emissão da raiz primária (PER).}

Este trabalho teve como objetivo estudar a emissão da raiz primária de sementes de milho, conforme método proposto por Toledo et al., (1995), em comparação com outros testes, visando a sua utilização como um indicador do vigor do referido material.

a) Instalação

Seis subamostras de 100 sementes, obtidas ao acaso de cada uma das amostras, foram distribuídas sobre três folhas de papel germitest, cobertas com duas folhas e enroladas à semelhança do teste padrão de germinação. $O$ umedecimento realizado, antes da semeação, correspondeu a 2,5 vezes o peso do papel.

b) Temperaturas (modalidades).

Após a semeadura, dois rolos de papel, correspondentes a cada amostra (lote), foram colocados em três germinadores separados às temperaturas de 20,25 e $30^{\circ} \mathrm{C}$ constantes, constituindo assim variações deste ensaio. Cada modalidade foi estudada isoladamente.

c) Avaliações.

Decorridas 24,0 horas após a entrada dos materiais nos aparelhos, os rolos foram retirados $e$ avaliados. A avaliação consistiu no cômputo e eliminação das cariopses cujas raízes primárias haviam rompido o pericarpo e 
emergido. Os rolos voltaram aos germinadores e sofreram reavaliação a cada 12,0 horas até o momento em que se encerrou a emissão da raiz primária.

No final das contagens, com os dados obtidos foi calculada a precocidade da emissão da raiz primária (PER) para cada lote, conforme as modalidades do presente teste, utilizando-se a seguinte formula:

$$
P E R=\frac{E_{1}}{1}+\frac{E_{2}}{2} \ldots \ldots \ldots \ldots \frac{E_{n}}{n} \text {., à semelhança do ensaio de velocidade }
$$

de germinação (Maguire, 1962), onde:

PER = precocidade da emissão da raiz primária.

$E_{1}, E_{2}, E_{n}=$ primeira, segunda e última contagem do número de sementes com emissão de raiz primária.

$1,2, n=$ divisores da primeira $(24,0 \mathrm{~h})$, segunda $(36,0 \mathrm{~h})$ e demais contagens sucessivas até o encerramento.

\subsection{Outros testes}

Concomitantemente foram conduzidos testes de laboratório e de campo com o objetivo de coletar dados sobre os vinte lotes e também para promover a comparação com os resultados do ensaio anterior em suas três modalidades $\left(20,25\right.$ e $\left.30^{\circ} \mathrm{C}\right)$. 


\subsubsection{Teste padrão de germinação (TPG)}

Foi conduzido com quatro subamostras de 50 sementes, de cada lote, em germinador regulado à temperatura constante de $30^{\circ} \mathrm{C}$, utilizando-se o papel toalha umedecido com água corrente na razão de 2,5 vezes o peso do substrato. A contagem das plântulas deu-se no quarto e no sétimo dias após a semeadura, seguindo os procedimentos estabelecidos pelas Regras para Análise de Sementes (Brasil, 1992).

\subsubsection{Primeira contagem de germinação}

Foi realizada em conjunto com o teste padrão de germinação considerando a porcentagem de plântulas normais (Brasil, 1992) obtida no quarto dia após a semeadura.

\subsubsection{Teste de emergência das plântulas em areia}

Foram semeadas quatro subamostras de 50 sementes em caixas plásticas $(42 \times 28 \times 10 \mathrm{~cm})$. Como substrato se utilizou areia esterilizada de textura média, colocada nas caixas formando uma camada de aproximadamente $6 \mathrm{~cm}$ de espessura. Em seguida dividiu-se a superfície em 4 partes iguais onde cada subamostra foi distribuída de maneira uniforme e coberta com uma camada de areia de $2 \mathrm{~cm}$ de espessura. 0 substrato foi umedecido na razão de $70 \%$ de sua capacidade de retenção de água. 0 teste foi mantido em condições ambientais (laboratório) e 10 dias depois da instalação procedeu-se à contagem das plântulas emersas. $O$ resultado foi expresso em porcentagem conforme Marcos Filho et al ., (1987). 


\subsection{4. Índice de velocidade de emergência}

Determinou-se em conjunto com o teste de emergência em areia (item 3.4.3.). As avaliações foram realizadas diariamente, à mesma hora, sendo contadas as plântulas que atingiram $3 \mathrm{~cm}$ de altura, entre $o$ terceiro e 0 décimo dia após a instalação. Para o cálculo do índice usou-se a formula indicada por Maguire (1962).

\subsubsection{Teste de frio com solo}

Foi realizado aplicando-se o estresse térmico de $10^{\circ} \mathrm{C}$ sobre as sementes, conforme as recomendações de Cícero \& Vieira (1994). Em caixas de plástico $(42 \times 28 \times 10 \mathrm{~cm})$, contendo uma camada de aproximadamente $6 \mathrm{~cm}$ de espessura da mistura de 2/3 de areia e 1/3 de solo proveniente de área cultivada com milho, foram distribuídas as quatro repetições (subamostras) de 50 sementes de cada lote, sendo cobertas com $2 \mathrm{~cm}$ da mistura, pressionando-se levemente a superfície. $O$ substrato foi umedecido na razão de $60 \%$ de sua capacidade de retenção. Esses recipientes, depois de receberem as sementes, permaneceram em câmara fria $\left(98 \%\right.$ UR e $\left.10^{\circ} \mathrm{C}\right)$ durante 7 dias. Em seguida, foram transferidos para ambiente normal (laboratório). Decorridos 7 dias, procedeu-se à contagem das plântulas que se encontravam emersas, conforme estabeleceram Marcos Filho et al .,(1987).

\subsubsection{Teste de envelhecimento precoce}

Realizado em gerboxes adaptados para o teste, em número de duas caixas por lote. Cada uma recebeu $40 \mathrm{ml}$ de água em sua base e 110 
sementes sobre a tela metálica inoxidável. Foram, então, fechadas e levadas para uma incubadora regulada a $42^{\circ} \mathrm{C}$, onde permaneceram por 72 horas, conforme recomendam Dias \& Barros (1995). Decorrido o tempo de permanência na câmara, quatro repetições de 50 sementes, por lote (amostra), foram distribuídas em rolo de papel e colocadas para germinar a $30^{\circ} \mathrm{C}$. A interpretação dos resultados deu-se no $4^{\circ}$ dia após a semeadura, computandose a porcentagem média de plântulas normais e sementes mortas por lote, adotando-se critério semelhante ao do TPG.

\subsubsection{Teste de condutividade elétrica}

Esta variável foi determinada em todas as amostras por meio do método de condutividade de massa, à semelhança do indicado pelo Comitê de Vigor da AOSA (1983), utilizando-se 4 repetições (submostras) de 50 sementes. Após a pesagem de cada subamostra, foram elas colocadas em copos plásticos onde receberam $75 \mathrm{ml}$ de água destilada. A seguir, os recipientes foram levados a uma câmara regulada à temperatura de $20^{\circ} \mathrm{C}$, onde permaneceram durante 24 horas. Ao final deste período procedeu-se à leitura da condutividade elétrica da solução utilizando-se o aparelho Digimed CD-20. Os resultados foram expressos em $\mu \mathrm{mhos} / \mathrm{g}$ de semente, obtendo-se a condutividade média por lote, de acordo com Dias \& Barros (1995).

\subsubsection{Teste de emergência de plântulas em campo}

Foi conduzido com 4 subamostras de 50 sementes por lote, sob irrigação artificial. Cada unidade experimental era constituída por uma linha de $2 \mathrm{~m}$ de comprimento, onde distribuíam-se as 50 sementes, espaçadas entre si 
de $0,04 \mathrm{~m}$, em sulcos de cerca de $0,07 \mathrm{~m}$ de profundidade e cobertas com 0,03 $\mathrm{m}$ de solo, sendo o espaçamento entre linhas de $0,30 \mathrm{~m}$. As contagens foram realizadas aos 15 dias após a semeadura, sendo, em seguida, calculada a porcentagem de plântulas por lote, observando-se os critérios recomendados por Nakagawa (1994).

\subsubsection{Altura de plântula}

Após a avaliação da porcentagem de emergência no campo foram medidas cinco plântulas escolhidas ao acaso, de cada repetição (subamostra), considerando o seu comprimento do nivel do solo até a extremidade da folha mais alta. Com os dados obtidos foi calculada a altura média por subamostra, conforme Nakagawa (1994).

\section{5. Épocas}

Todos os testes apresentados foram instalados em três épocas distintas, a saber: janeiro, abril e julho de 1996. Adotou-se três épocas a fim de se intensificar o estudo e se chegar a informações confiáveis. 


\subsection{Informações complementares}

\subsubsection{Teor de água}

O teor de água das sementes foi avaliado pelo método da estufa a $105 \pm 3^{\circ} \mathrm{C}$ por $24 \mathrm{~h}$, conforme as Regras para Análise de Sementes (Brasil, 1992). Os valores obtidos encontram-se na Tabela 1.

\subsubsection{Dados climáticos}

Os dados referentes à precipitação pluvial $(\mathrm{mm})$ e a temperatura $\left({ }^{\circ} \mathrm{C}\right)$ máxima e mínima do ar, procedentes do Posto Meteorológico, no Departamento de Física e Meteorologia da ESALQ, durante o período de agosto de 1995 até julho de 1996, estão apresentados na Figura 1 e na Tabela $1 \mathrm{~A}$ (Apêndice).

\subsubsection{Dados das condições ambientais do LAS.}

As informações sobre a umidade relativa do ar (\%) e temperaturas médias $\left({ }^{\circ} \mathrm{C}\right)$, durante 0 período de janeiro a agosto de 1996 , ocorridas no Laboratório de Sementes do Departamento de Agricultura, se encontram na Figura 2 e na Tabela 2A (Apêndice). 
Tabela 1. Valores médios do teor de água (\%) dos vinte lotes de sementes de milho híbrido AG-510 avaliados em três épocas. Piracicaba, SP., 1996.

\begin{tabular}{lcccc}
\hline & \multicolumn{3}{c}{ Épocas } & Médias \\
\cline { 2 - 4 } Lotes & janeiro & abril & julho & Me, \\
\hline 1 & 11,9 & 10,4 & 9,9 & 10,7 \\
3 & 11,9 & 10,5 & 10,1 & 10,8 \\
4 & 12,4 & 10,8 & 10,3 & 11,2 \\
5 & 12,0 & 10,6 & 10,2 & 10,9 \\
6 & 12,1 & 10,6 & 10,2 & 11,0 \\
7 & 11,5 & 10,7 & 10,5 & 10,9 \\
8 & 12,1 & 10,5 & 10,1 & 10,9 \\
9 & 11,9 & 10,3 & 10,0 & 10,7 \\
10 & 12,5 & 10,3 & 10,1 & 10,9 \\
11 & 12,4 & 9,9 & 9,5 & 10,6 \\
12 & 12,3 & 10,1 & 9,9 & 10,8 \\
13 & 12,6 & 10,4 & 9,8 & 10,9 \\
14 & 11,7 & 10,1 & 9,9 & 10,6 \\
15 & 12,1 & 10,1 & 10,7 & 11,0 \\
16 & 12,6 & 9,8 & 10,2 & 10,9 \\
17 & 12,4 & 9,8 & 10,4 & 10,9 \\
18 & 12,0 & 10,1 & 10,3 & 10,8 \\
19 & 12,2 & 10,1 & 10,4 & 10,9 \\
20 & 12,0 & 9,6 & 10,0 & 10,5 \\
\hline & 11,6 & 9,8 & 9,9 & 10,4 \\
\hline
\end{tabular}




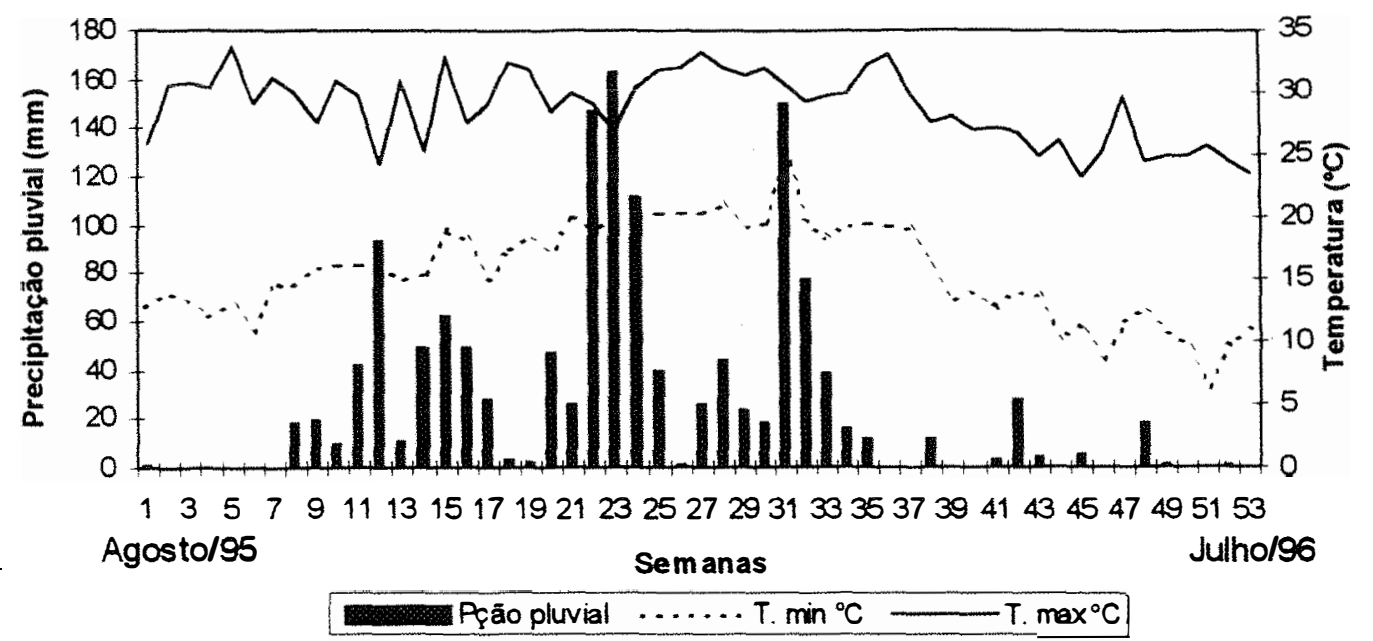

Figura 1. Valores médios da precipitação pluvial (histograma) e temperatura máxima e mínima $\left({ }^{\circ} \mathrm{C}\right)$ semanais em Piracicaba, SP., no período de agosto de 1995 a julho de 1996.

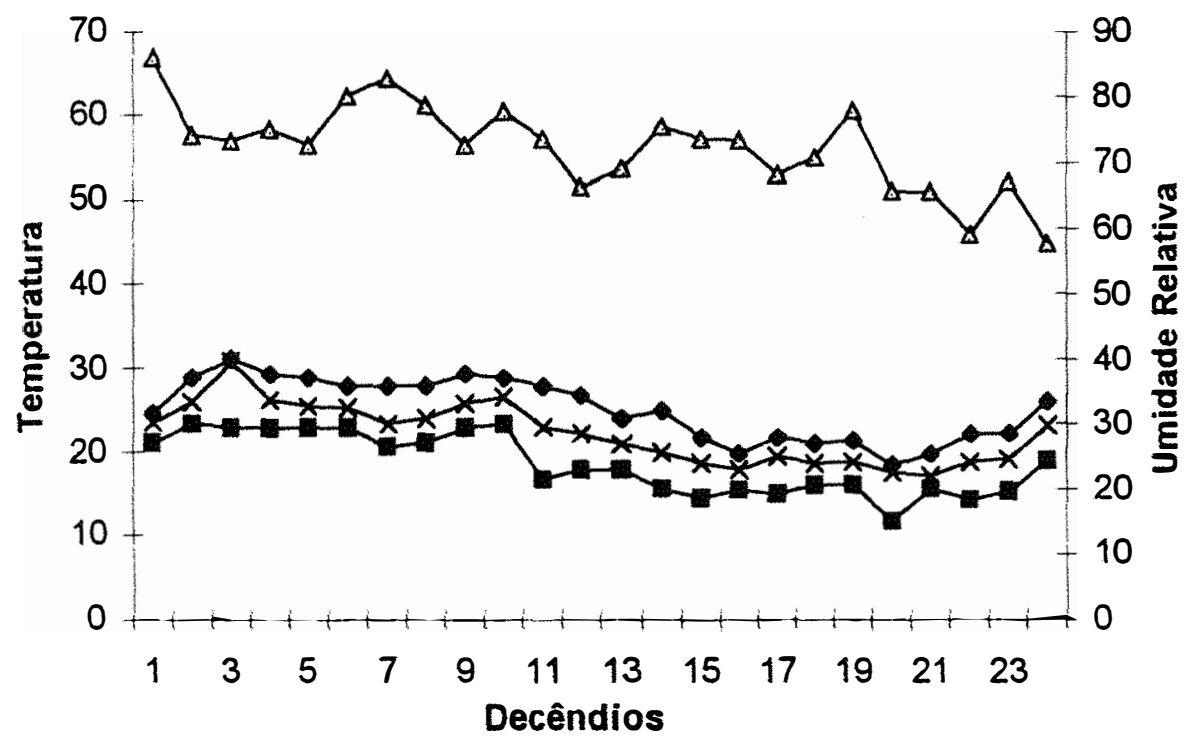

$*$ T. média $\left({ }^{\circ} \mathrm{C}\right) \multimap T$. máxima $\left({ }^{\circ} \mathrm{C}\right) \rightarrow-$ T.minima $\left({ }^{\circ} \mathrm{C}\right) \rightarrow U$. relativa $(\%)$

Figura 2. Valores médios da umidade relativa (\%) e temperatura média, máxima e mínima $\left({ }^{\circ} \mathrm{C}\right)$ no ambiente do Laboratório de Analise de Sementes, no período de janeiro a agosto de 1996. 


\subsection{Procedimentos estatísticos}

Os índices calculados a partir dos dados de precocidade de emissão da raiz primária e velocidade de emergência das plântulas em areia foram transformados em raiz quadrada de $x+0,5$, enquanto os dados dos testes de germinação, emergência das plântulas em areia, primeira contagem, frio, envelhecimento precoce e emergência de plântulas em campo foram transformados em arco seno da raiz quadrada de $x / 100$. Por outro lado, os dados da altura de plântula e condutividade elétrica ficaram sem transformações. Os valores obtidos foram analisados empregando-se 0 delineamento completamente ao acaso e o de blocos ao acaso, conforme Gomes (1978). A análise de variância foi conduzida isoladamente para cada teste inclusive modalidades e épocas (Tabelas 2 e 3 ) bem como para o conjunto de épocas (Tabela 4).

Tabela 2. Esquema da análise da variância dos índices de precocidade de emissão de raiz primária nas temperaturas de 20,25 e $30^{\circ} \mathrm{C}$, aplicados sobre os lotes de sementes, por época.

\begin{tabular}{ll}
\hline Causas de variação & G.L \\
\hline Lotes & 19 \\
Resíduo & 20 \\
\hline Total & 39 \\
\hline
\end{tabular}


Tabela 3. Esquema da análise da variância dos dados obtidos dos demais testes aplicados sobre os lotes de sementes, por época.

\begin{tabular}{ll}
\hline Causas de variação & G.L \\
\hline Lotes & 19 \\
Resíduo & 60 \\
\hline Total & 79 \\
\hline \hline
\end{tabular}

Tabela 4. Esquema da análise de variância, do conjunto de épocas, para cada teste usado sobre os lotes de sementes.

\begin{tabular}{lc}
\hline Causas de variação & G.L \\
\hline Lotes & 19 \\
Repetições (épocas) & 02 \\
Resíduo & 38 \\
\hline Total & 59 \\
\hline \hline
\end{tabular}

Complementando estas análises, as médias de cada lote foram comparadas pelo método de Tukey, ao nível de $5 \%$ de probabilidade e calculadas as correlações simples entre todos os testes efetuados. Para realizar essas operações foi empregado 0 sistema de análise estatística para microcomputadores SANEST (Zonta et al., 1984).

\subsection{Apêndice}

Além das Tabelas $1 \mathrm{~A}$ e $2 \mathrm{~A}$ foram apresentadas as contagens referentes ao PER a 20,25 e $30^{\circ} \mathrm{C}$, na Tabela $3 \mathrm{~A}$. 


\section{RESULTADOS}

\subsection{Precocidade da emissão da raiz primária (PER).}

A análise de variância dos dados da avaliação por época e da análise conjunta revelou valores de $F$ significativos para 0 efeito de lotes, obtendo-se coeficientes de variação na faixa de 0,88 a 1,77 . Procedeu-se, então, o exame dos valores médios dos lotes para cada uma das modalidades deste teste, o qual em seguida será apresentado.

A comparação dos dados do teste PER a $20^{\circ} \mathrm{C}$ (Tabela 5), referentes as determinações realizadas, indicaram variação no comportamento dos lotes dentro das diferentes épocas. Assim, em termos de significância estatística $(P<0,05)$, logrou-se definir lotes que, de maneira geral, podem ser agrupados, com base no valor alcançado e frequência com que participaram nas épocas de avaliação. Neste sentido, os lotes que integraram o grupo de maior índice, nas três épocas, foram os seguintes: $4,5,10,3,9$ e 6 . 0 grupo de baixo índice envolveu, principalmente, os lotes 16, 18, 19, 15 e 20.

Já a análise conjunta revelou uma estratificação mais definida dos materiais, porém nota-se que o teste destacou cinco lotes com maior PER, o 4 como superior, vindo depois o 5 e em continuação 10,9 e 3 respectivamente. Por sua vez, os lotes 18,19 e 20 mostraram os mais baixos valores. 


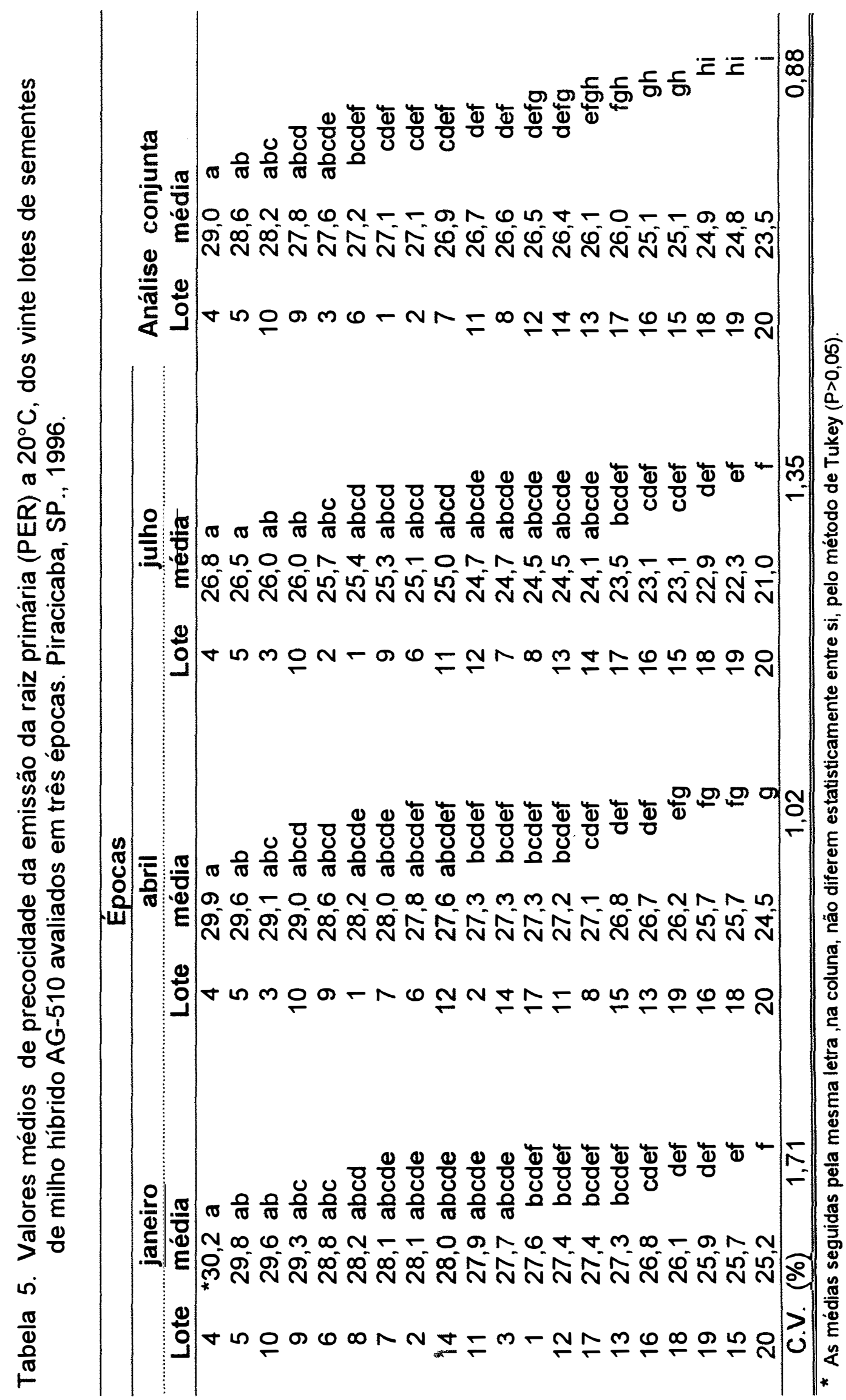


As determinações do teste PER a $25^{\circ} \mathrm{C}$ (Tabela 6) revelaram menor variação do desempenho dos lotes nas épocas de estudo; esta situação assinalou uma certa diferença com a modalidade a $20^{\circ} \mathrm{C}$. Neste caso, à variação entre lotes destacou razoavelmente dois grupos em relação à precocidade, tendo o de maior atingido $85 \%$ do material e o restante integrouse no grupo de valores menores.

Paralelamente, a análise conjunta mostrou os seis melhores lotes que representaram $30 \%$ do total, notando-se que outra vez o lote 4 foi superior, seguido pelo 5 e depois os lotes $10,1,9$ e 2 . Por outro lado, os lotes que apresentaram os menores resultados foram 18,15, 19 e por último o lote 20.

Para O PER a $30^{\circ} \mathrm{C}$ (Tabela 7) os dados indicaram que houve comportamento menos uniforme entre épocas do que o constatado nos dois casos anteriores, mas pode-se observar que 0 teste foi eficiente para estratificar os lotes dentro de cada época e, em termos gerais, também mostrou grupos de alto e de baixo índice de precocidade. Assim, se evidenciou que, dentro das épocas e na análise conjunta, os seis melhores lotes foram os seguintes: o lote 11 como superior, seguido pelo 12, depois os lotes $10,4,5$ e 13. Por outro lado, dentre os que apresentaram os menores resultados estão: 0 lote 18 e 8 , seguidos por 7 e 6 .

Paralelamente, o exame da Figura 3, permitiu verificar o comportamento dos lotes nas três temperaturas utilizadas; assim, os lotes manifestaram um maior indice de precocidade à medida que foram aumentadas as temperaturas. Também pode-se observar que existiu maior variação entre lotes à medida que se elevou a temperatura. 


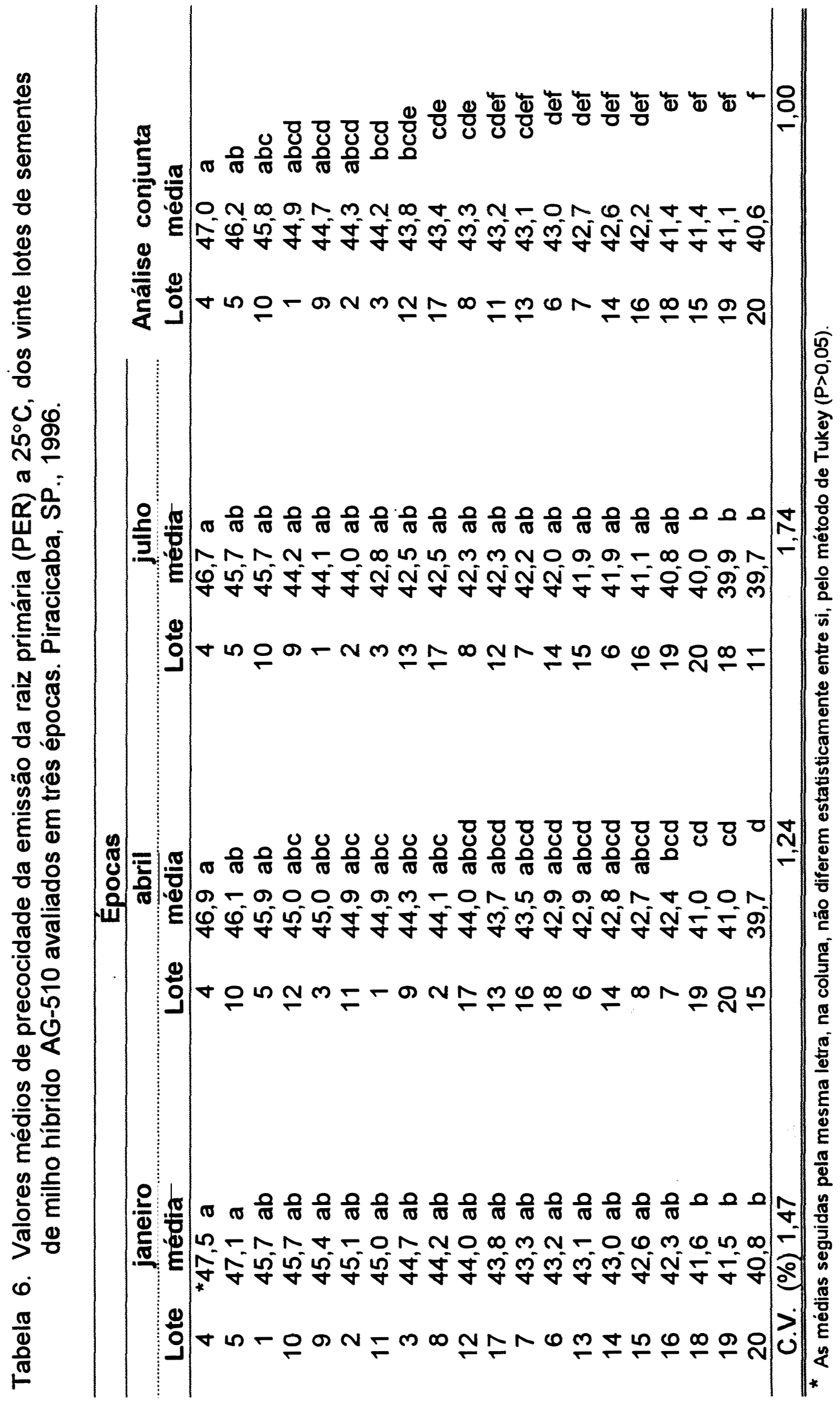




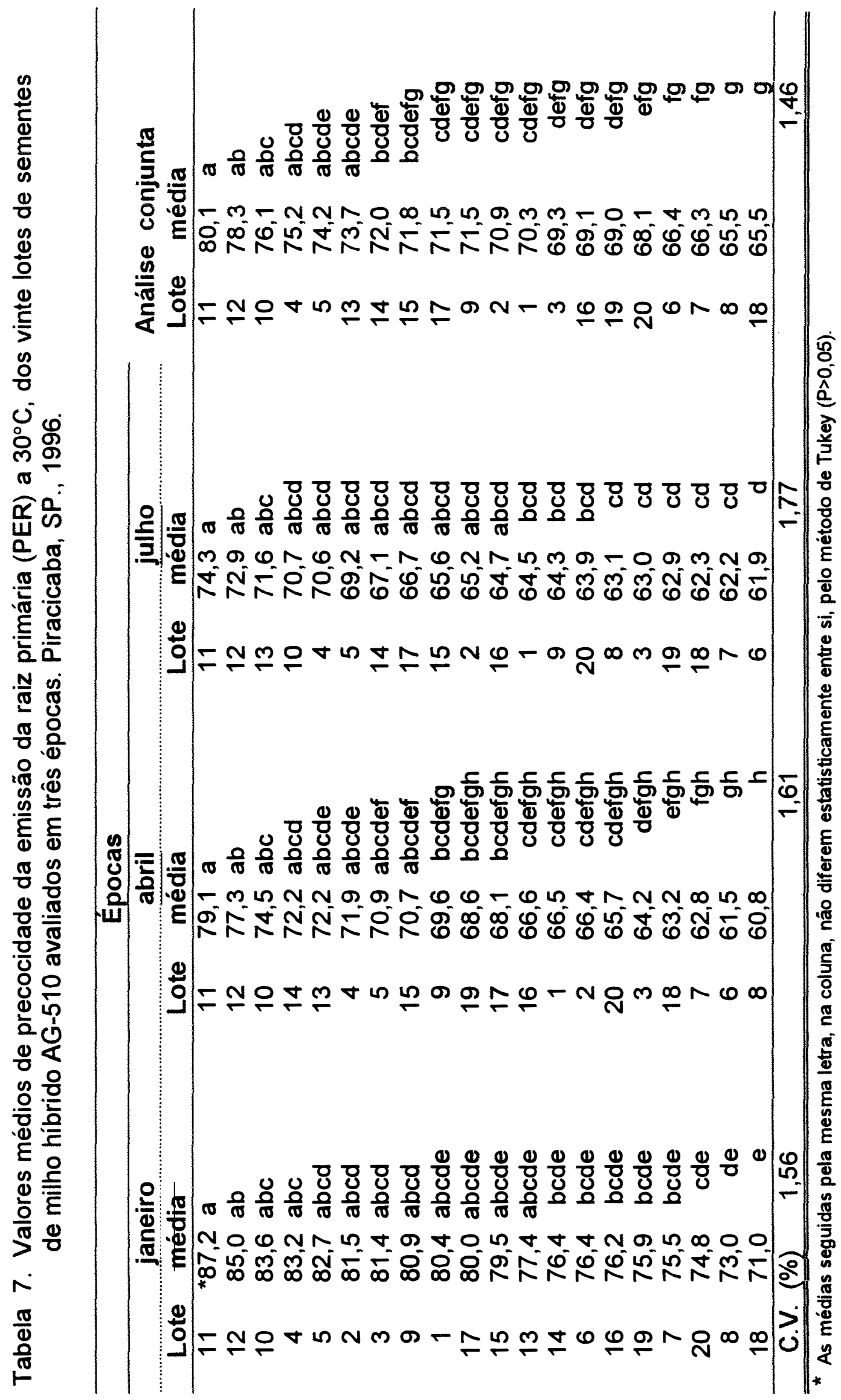


Verificou-se, ainda, que o período de avaliação (Figura 4) a $20^{\circ} \mathrm{C}$, iniciou-se às 48 horas e foi concluido 84 horas após a semeação. No caso do PER 25 e $30^{\circ} \mathrm{C}$ pode-se indicar que o período de avaliação foi o mesmo (24 a 48 horas) só que a frequência de emissão da raiz primária é maior para o período de 24 horas a $30^{\circ} \mathrm{C}$ do que a $25^{\circ} \mathrm{C}$.

\subsection{Outros testes utilizados}

Cabe assinalar que a análise de variância dos dados indicaram valores de $F$ significativos para $o$ efeito de lotes por épocas e em conjunto, para todos os parámetros estudados. Assim, em seguida, são examinadas as comparações das médias obtidas.

\subsubsection{Teste padrão de germinação (TPG)}

A Tabela 8 apresenta os resultados das porcentagens de germinação e os coeficientes de variação; estes ficaram na faixa de 3,36 a $4,33 \%$.

Como pode-se observar o método de Tukey acusou poucas diferenças significativas entre os lotes dentro da primeira e segunda épocas. Já na terceira a estratificação ficou mais definida, notando-se claramente um extrato superior com os lotes $5,4,2,6,8,10,1,3,7$ e 9 e $o$ inferior formado pelo $14,13,15,17,11,12,18,20,16$ e 19. 


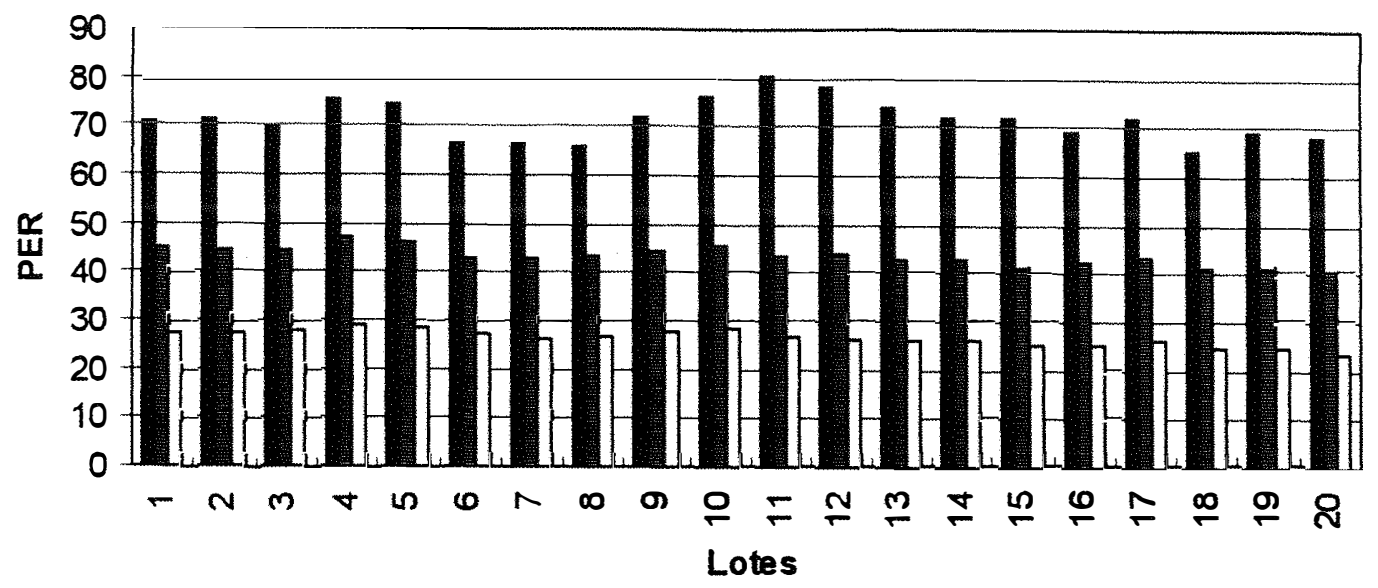

EPER- 30

물 PER- 25

口PER- 20

Figura 3. Comportamento dos vinte lotes de milho híbrido AG510 , em relação à precocidade da emissão de raiz primária da semente, quando submetidas ao teste a 30,25 e $20^{\circ} \mathrm{C}$ de temperatura (médias das três épocas).

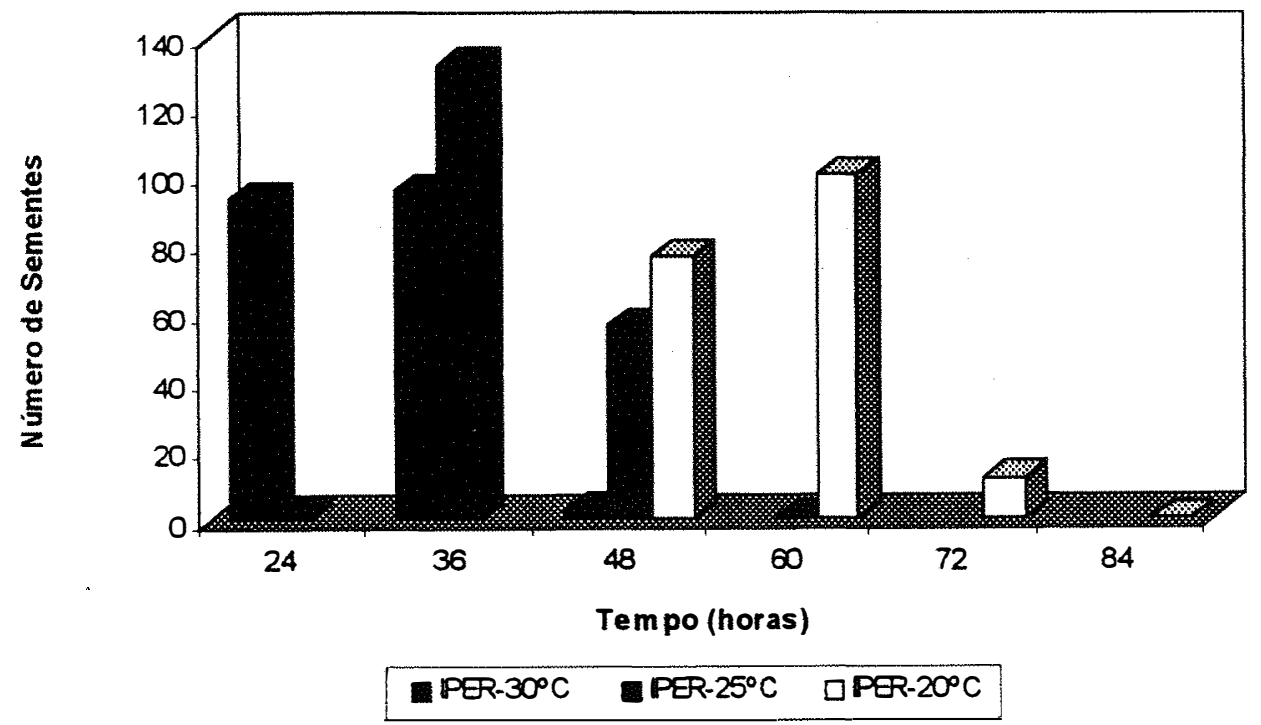

Figura 4. Emissão da raiz primária das sementes de milho híbrido AG-510, durante os períodos de exposição nos germinadores a 30,25 e $20^{\circ} \mathrm{C}$ (média dos vinte lotes nas três épocas). 


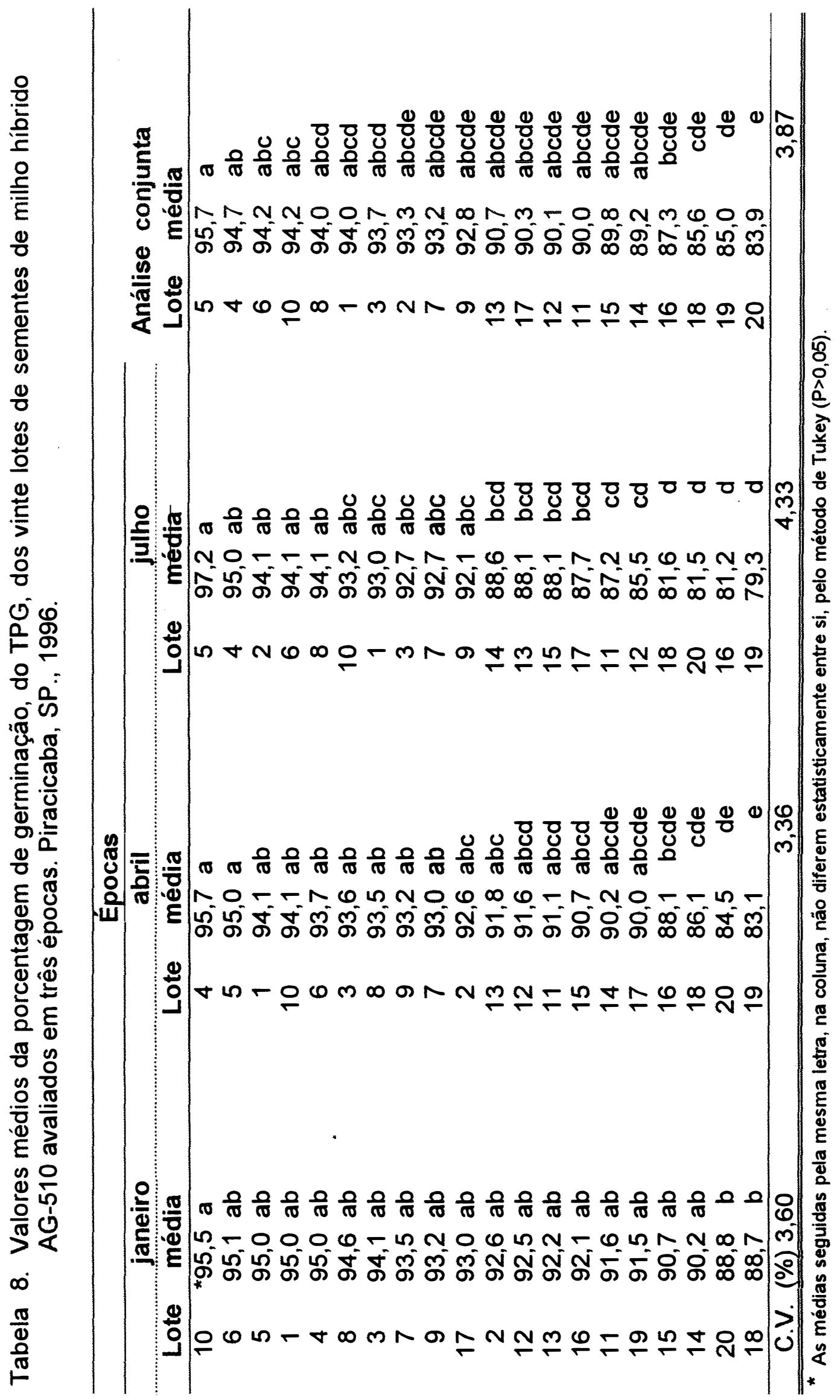


A análise conjunta, apesar das significâncias mostradas, não permitiu a observação de grupos bem distintos, porém, o lote 5 se destacou como o melhor e o 20 como o mais fraco.

\subsubsection{Primeira contagem de germinação}

Os valores médios para o efeito de lotes por época, a análise conjunta e os coeficientes de variação ( na faixa 2,41 a 3,99 \% ) encontram-se na Tabela 9.

Em relação ao exame por época, notou-se que a maior parte dos lotes com primeiras contagens superiores apareceram tanto na primeira e como na segunda época. A terceira época, porém, foi semelhante ao observado no TPG, onde o grupo de melhor desempenho foi integrado pelos lotes 1 a 10, tendo o 5 mostrado posição destacada.

A análise conjunta, por sua vez, também revelou analogia com o TPG, acusando diferenças estatísticamente significativas entre lotes. Observou-se tendência para destacar o lote 5 como superior e o 20 como menos vigoroso

\subsubsection{Teste de emergência das plântulas em areia}

$\mathrm{Na}$ Tabela 10 pode-se observar a comparação das médias das porcentagens de emergência para o efeito de lotes por época, a análise conjunta e os coeficientes de variação que se situaram na faixa de 3,14 a $7,21 \%$. 


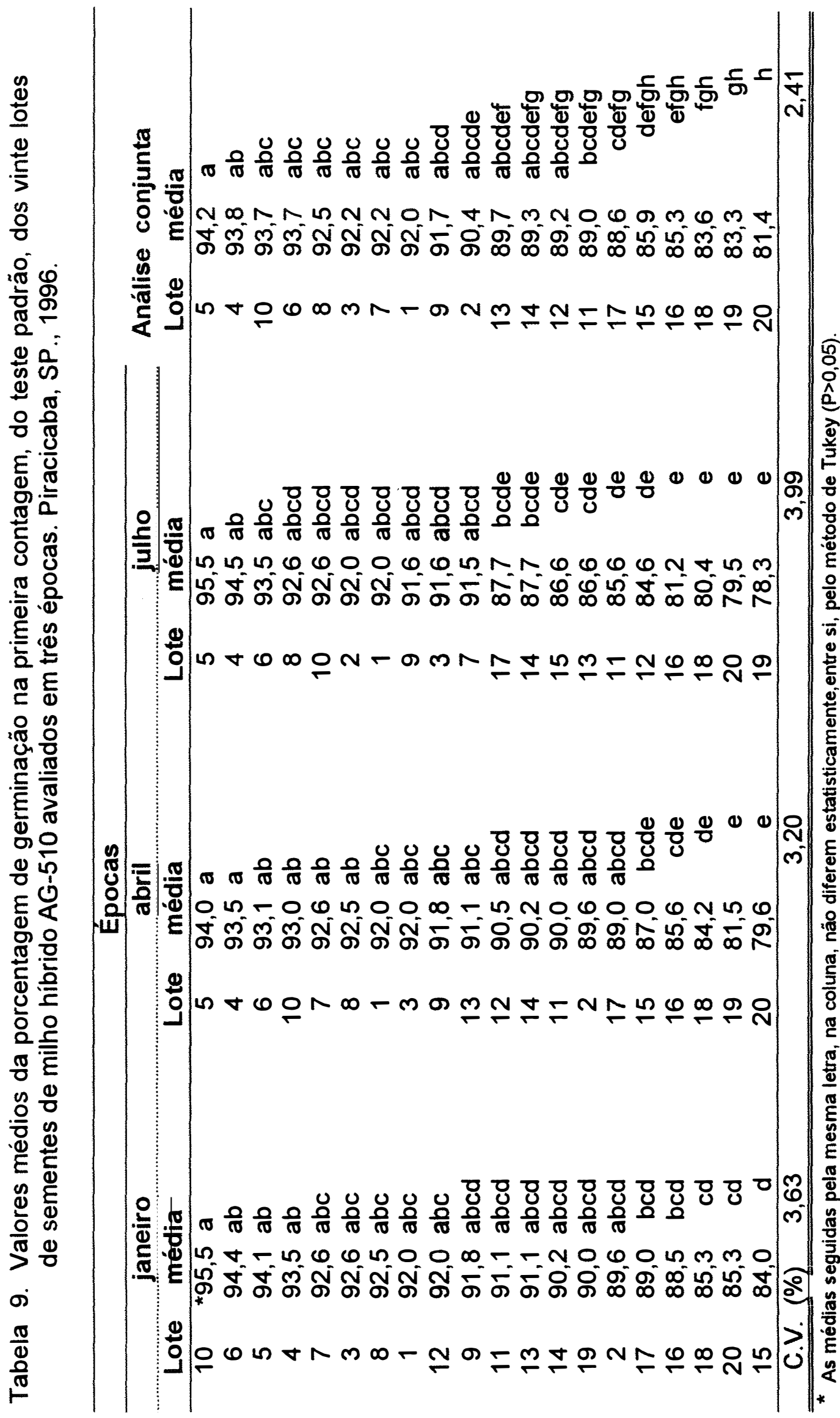




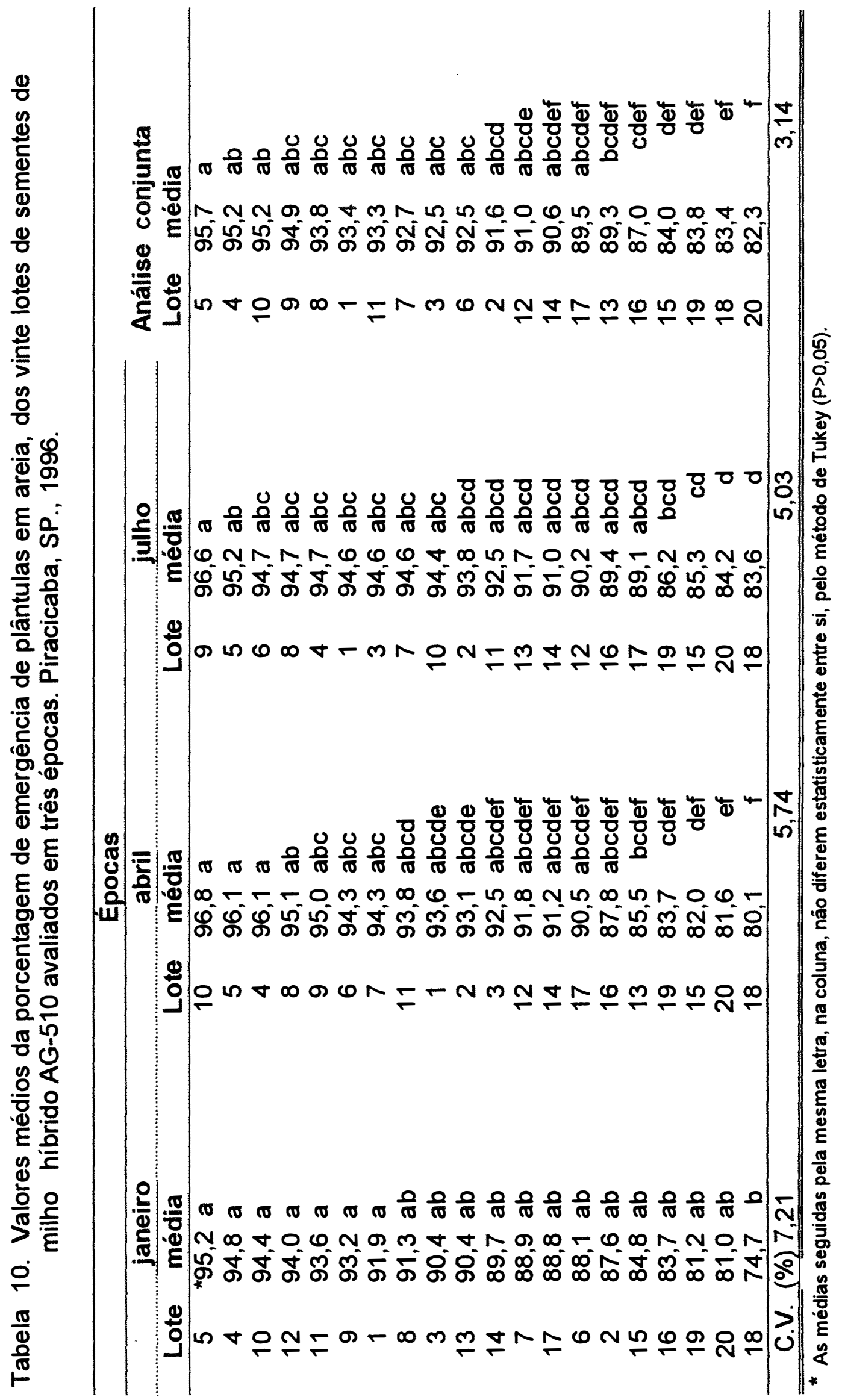


O exame dos resultados das avaliações realizadas evidencia que em janeiro o comportamento dos lotes foi mais homogêneo que nas outras épocas, pois apresentaram apenas dois niveis ou classes de significância. $\mathrm{Na}$ segunda e terceria épocas se observou maior estratificação (variação) entre os lotes.

A análise conjunta também revelou sobreposição das classes com significância estatística, destacando-se o 5 como superior, seguido pelos lotes 4 e 10. No grupo de menor potencial de emergência em areia ficaram os lotes 20, 18, 19, 15.

\subsubsection{Indice de velocidade de emergência em areia}

Os valores médios para o efeito de lotes em cada época, a análise conjunta e os coeficientes de variação (na faixa de 2,33 a 3,57) se encontram na Tabela 11.

Para o efeito de lotes obteve-se o seguinte: nas épocas primeira e segunda os valores dos índices de velocidade de emergência foram similares para a maioria dos materiais, observando-se, porém, diferentes agrupamentos em função das variações significativas. Por outro lado, na terceira época os indices mostraram forte redução em relação aos das épocas anteriores, sem todavia, deixar de apresentar a estratificação dos lotes.

A análise conjunta, como nos outros testes já interpretados, mostrou resultados semelhantes aos das épocas em separado, destacando-se os lotes 4 e 9 como superiores e em continuação 5 e 10 . Por outro lado, os de menor índice de velocidade de emergência foram 18, 20, 19, 15 e 16. 


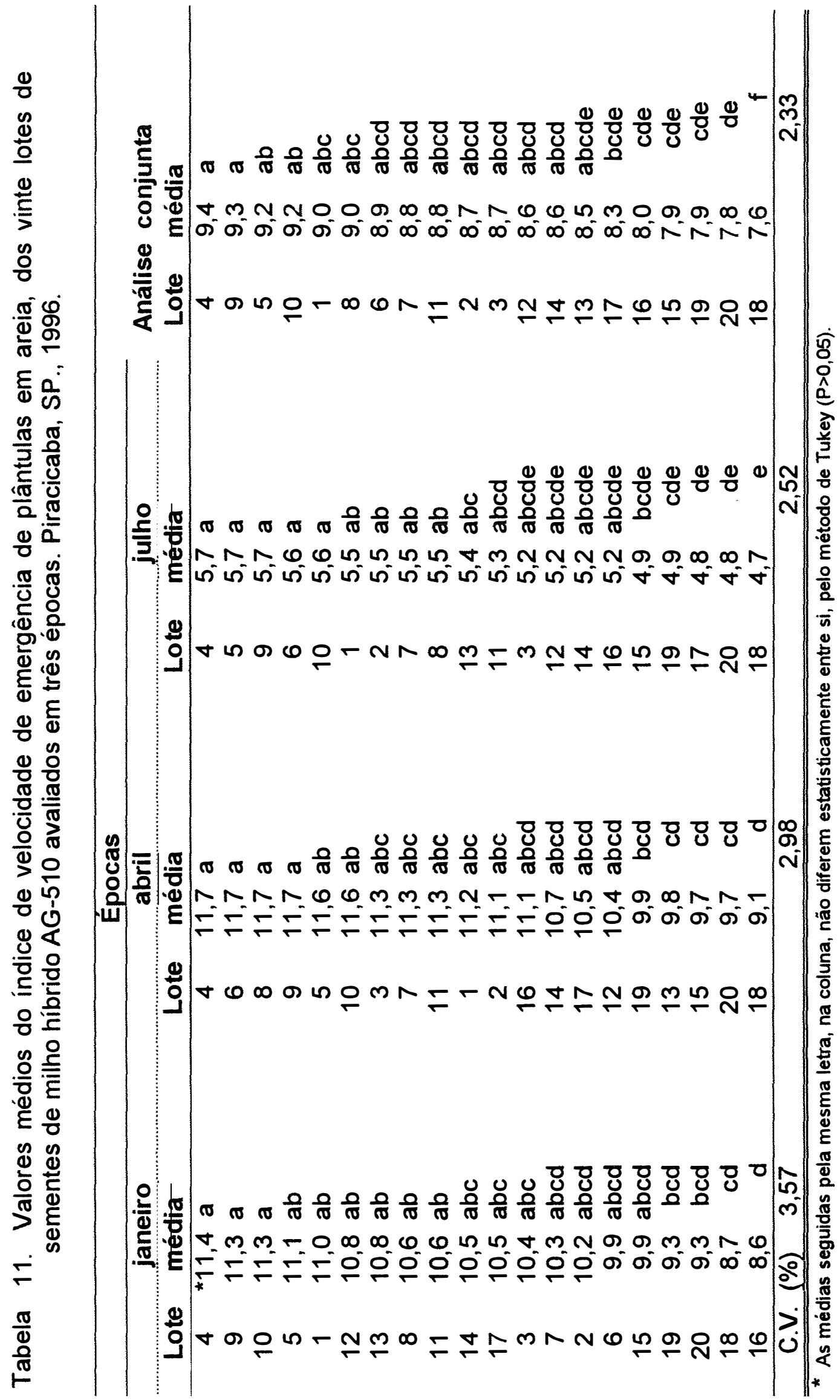




\subsubsection{Teste de frio com solo}

$\mathrm{Na}$ Tabela 12 se anotam os valores médios obtidos para o efeito de lotes por época, análise conjunta e os coeficientes de variação que ficaram na faixa de 3,05 a $5,76 \%$.

Os resultados revelaram que este teste promoveu separação consistente entre os materiais utilizados. Assim, os lotes 1 a 10 foram os melhores nas 3 épocas de avaliação. Essa resposta foi confirmada pela análise conjunta. Os lotes que tiveram as taxas de emergência mais baixas foram: 19 , 20,15 e 18.

\subsubsection{Teste de envelhecimento precoce}

Os resultados de plântulas normais e de sementes mortas obtidos para efeitos de lotes por época, análise conjunta e os coeficientes de variação na faixa de 5,96 a 16,98 \% consignam-se nas Tabelas 13 e 14 .

Cabe ressaltar que o teste foi eficiente para a estratificação dos lotes. Assim, os materiais de 1 a 10 se destacaram dos demais como os melhores, exceto os lotes 2 e 4 na primeira e 4 e 6 na segunda época. $\mathrm{Na}$ terceira ficaram no grupo de melhor desempenho, além dos lotes 1 a $10012 \mathrm{e}$ 14 e excluídos os lotes 6 e 7 . Não entanto, já na análise conjunta se reafirma a posição de todos os lotes de 1 a 10 , incluíndo-se 12 e 14 . Neste grupo se destacaram com os melhores valores médios de viabilidade $09,10,5$ e 8 . Entre os que revelaram menor taxa de viabilidade foram os lotes 18 e 19 , seguidos por 17,20 e 15 . 


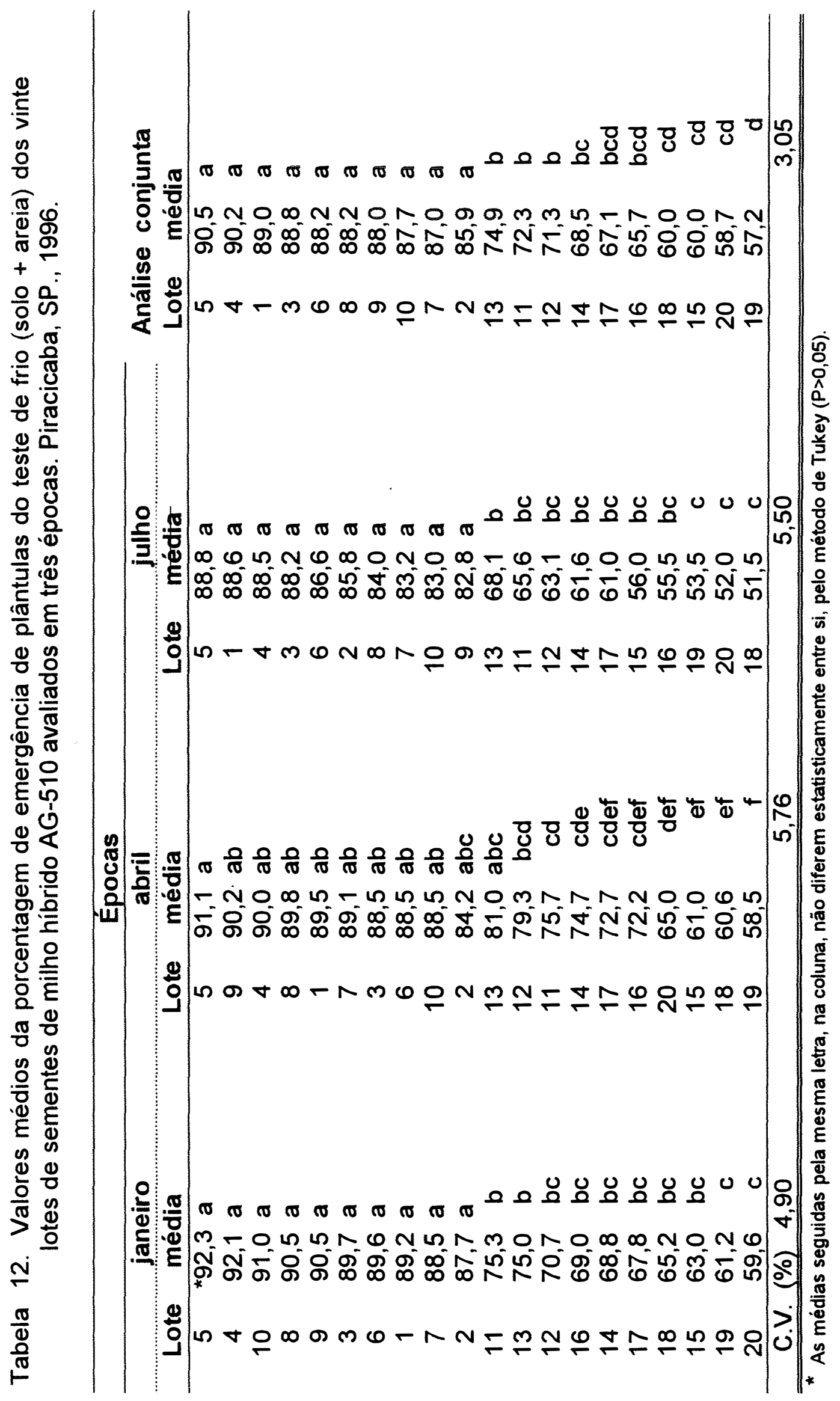




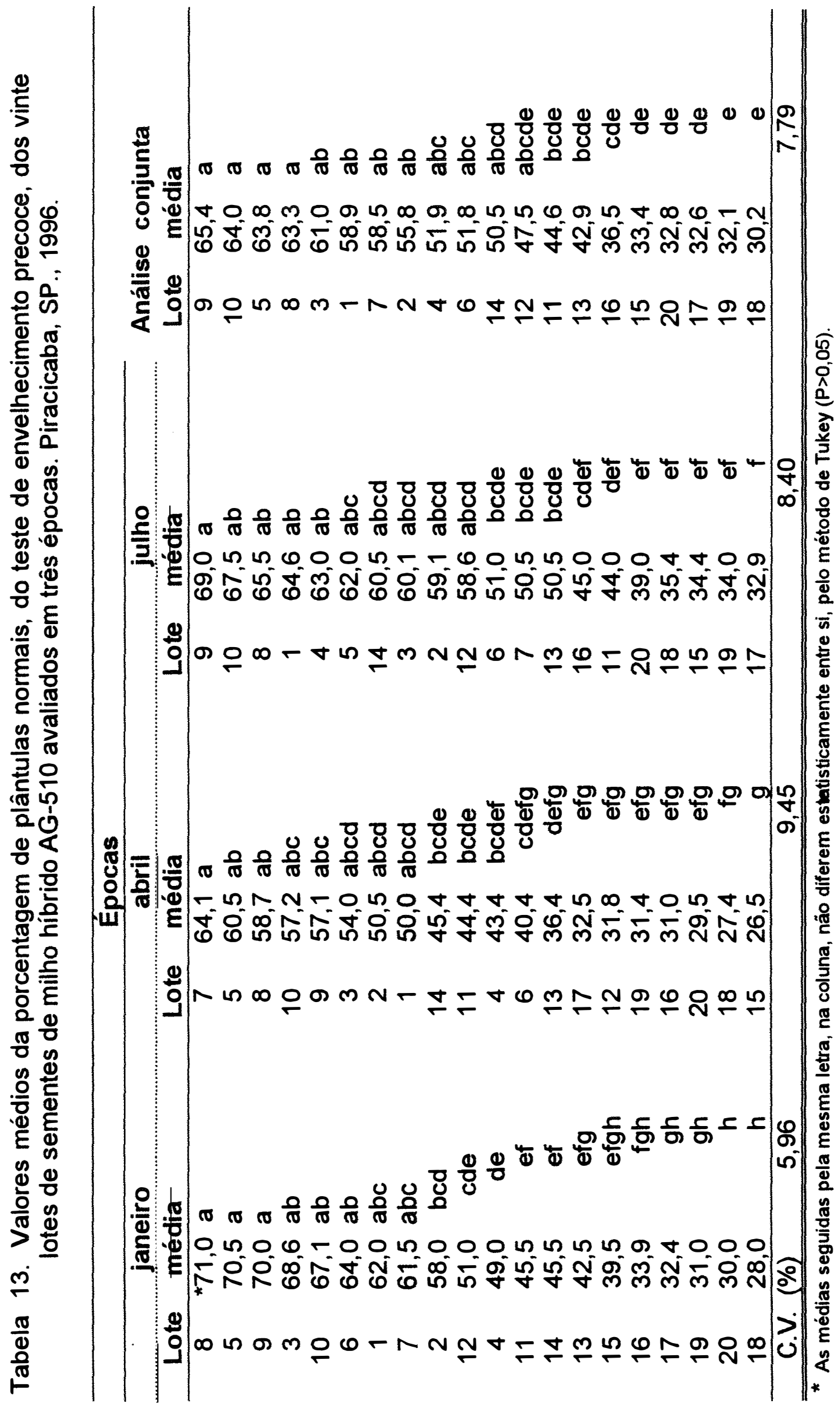




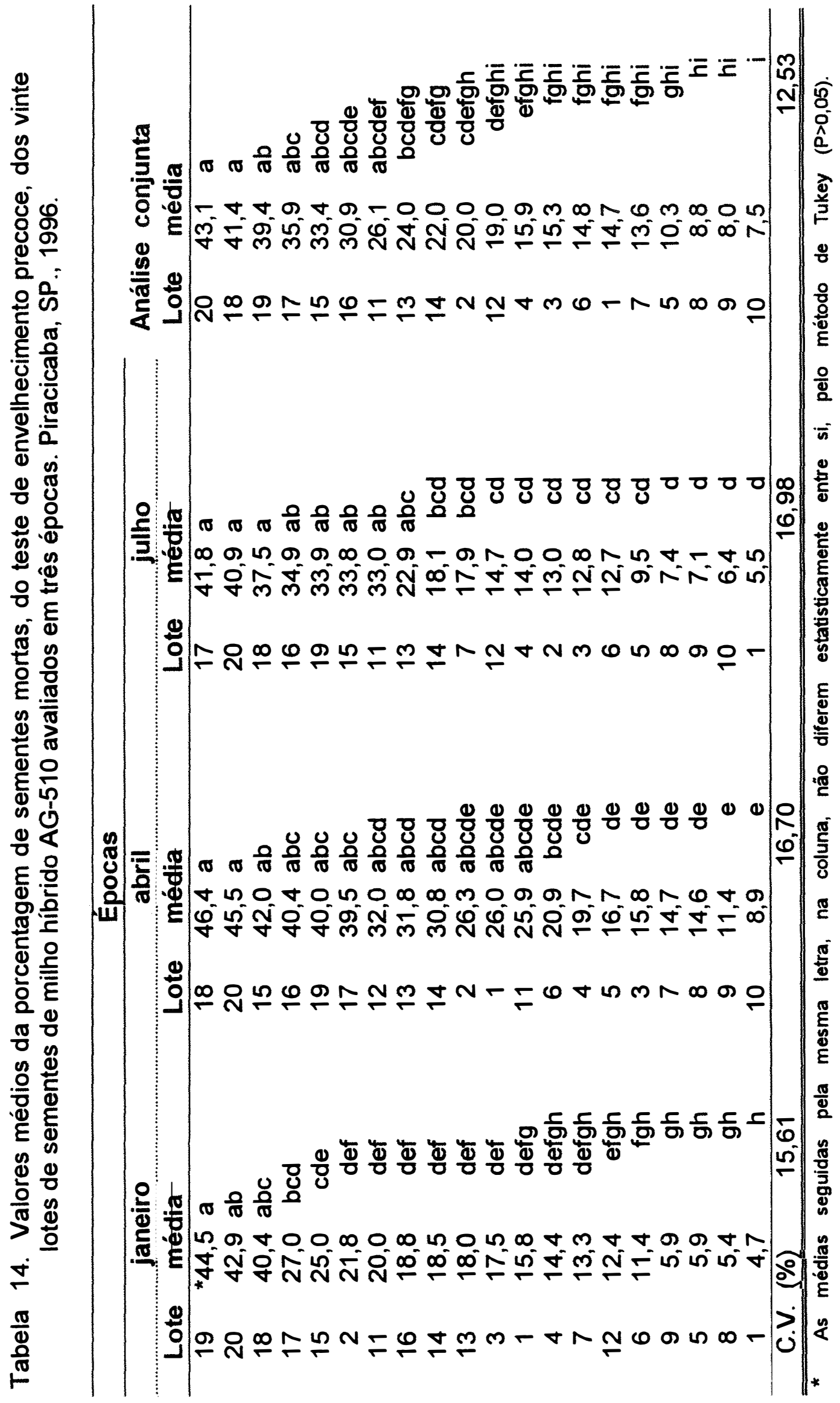


No caso dos efeitos sobre sementes mortas notou-se que na primeira época os lotes que apresentaram maiores porcentagens foram 19, 20 e 18. Na segunda época o número de materiais com superioridade estatística aumentou, abrangendo os lotes de 11 a 20, incluíndo também 1 e 2 . Já na terceira o grupo com maior taxa de sementes mortas passa a ser menor onde se agruparam os lotes $17,20,18,16,19,15,11$ e 13.

A tendência observada nas épocas foi confirmada pela análise conjunta. Porém, os lotes com maior taxa de sementes mortas foram, em primeiro lugar, o 20 e 18, seguidos pelos lotes 19,17, 15, 16 e 11. Aqueles que tiveram menor taxa de sementes mortas foram: 10, 9, 8 e 5 .

É interessante destacar que os coeficientes de variação observados neste teste forambem mais elevados do que nos outros casos.

\subsubsection{Teste de condutividade elétrica}

Os resultados obtidos para os efeitos dos lotes por época, a análise conjunta e os coeficientes de variação (na faixa de 6,45 a 9,15\%) registram-se na Tabela 15.

Observa-se que o comportamento dos lotes apresenta-se de maneira semelhante nas 3 épocas de avaliação, ficando por ordem de grandeza os lotes de 11 ao 20 entre os primeiros dez lugares. Verificou-se também que houve um acréscimo, não avaliado estatísticamente, no índice de condutividade, sendo maior na última época em relação às anteriores em todos os lotes. Porém, é importante destacar que os lotes de 1 a 10 mantiveram sua posição, formando grupo dos melhores lotes. 


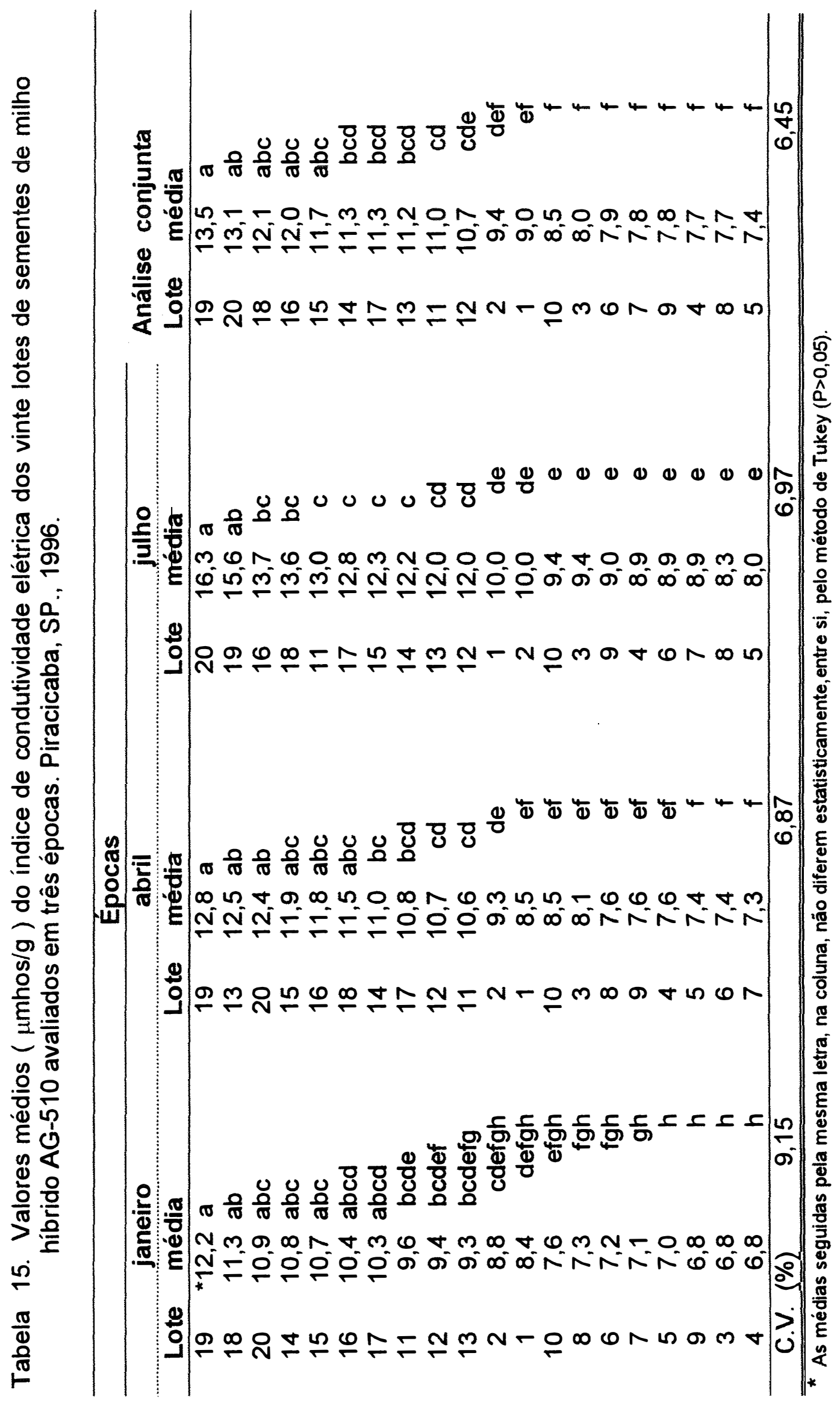


A análise conjunta confirma a resposta já indicada, tendo o lote 19 o maior índice de condutividade, vindo em seguida $20,18,16$ e 15 . Por sua vez, os que mostraram os menores valores foram $5,8,4,9,7,6,3$ e 10.

4.2.8. Teste de emergência de plântulas em campo

$\mathrm{Na}$ Tabela 16 se encontram os resultados obtidos para os efeitos de lotes por época, a análise conjunta e os coeficientes de variação os quais flutuaram entre 4,85 a $7,14 \%$.

Notou-se que o desempenho dos lotes foi similar nas duas primeiras épocas, onde a maior parte ficou no grupo de melhor desempenho. Por outro lado, na terceira época a estratificação foi maior e os lotes 1 a 10 , incluíndo o 13 continuaram no grupo de melhor comportamento.

Ao examinar a análise conjunta, confirmou-se os resultados observados na primeira e segunda épocas, quando o teste não mostrou diferenças significativas entre a maioria dos lotes.

\subsubsection{Altura de plântula}

$\mathrm{Na}$ Tabela 17 apresentam-se os valores médios obtidos para efeitos de lotes por épocas, a análise conjunta e os coeficientes de variação na faixa de 3,30 a $8,32 \%$. 


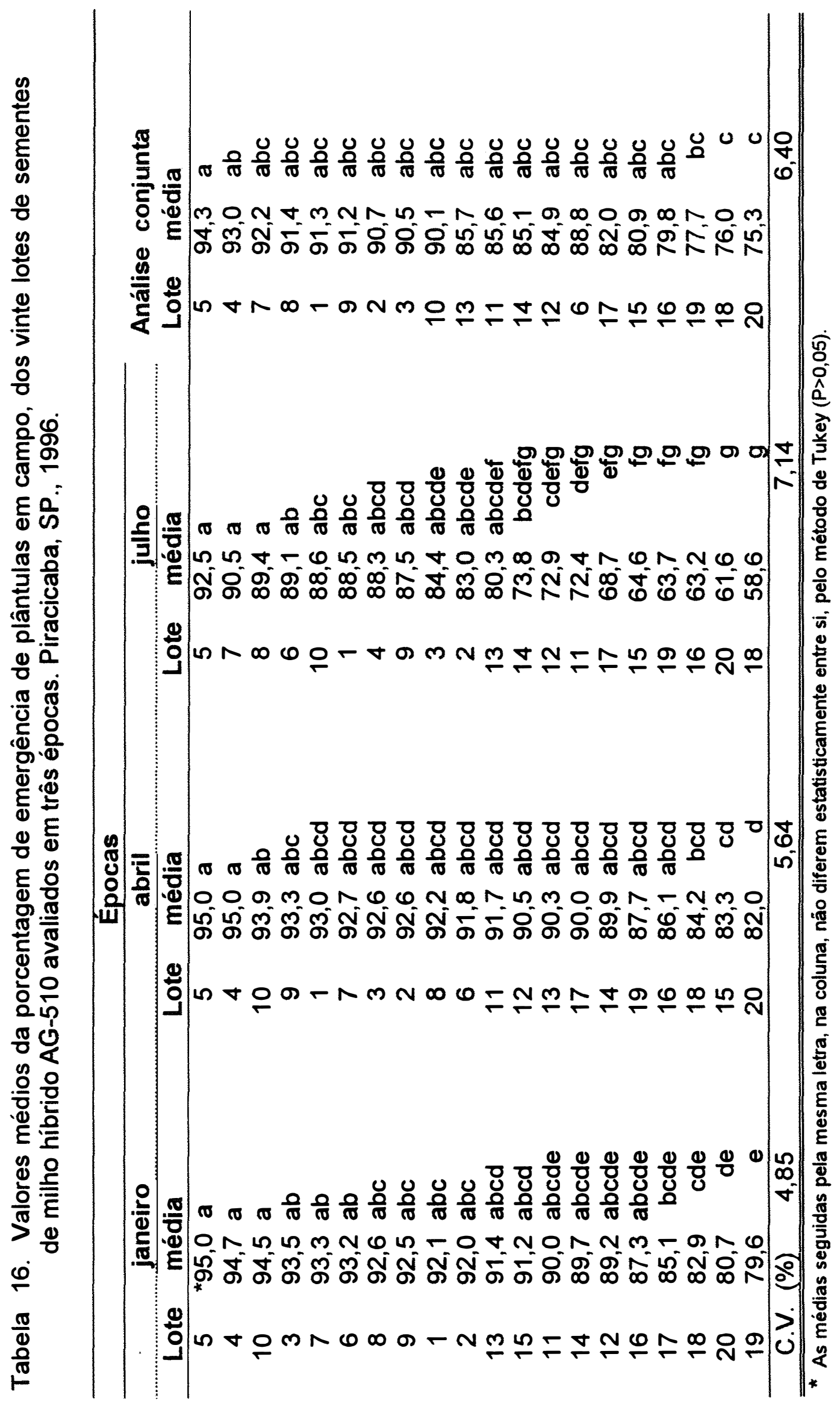




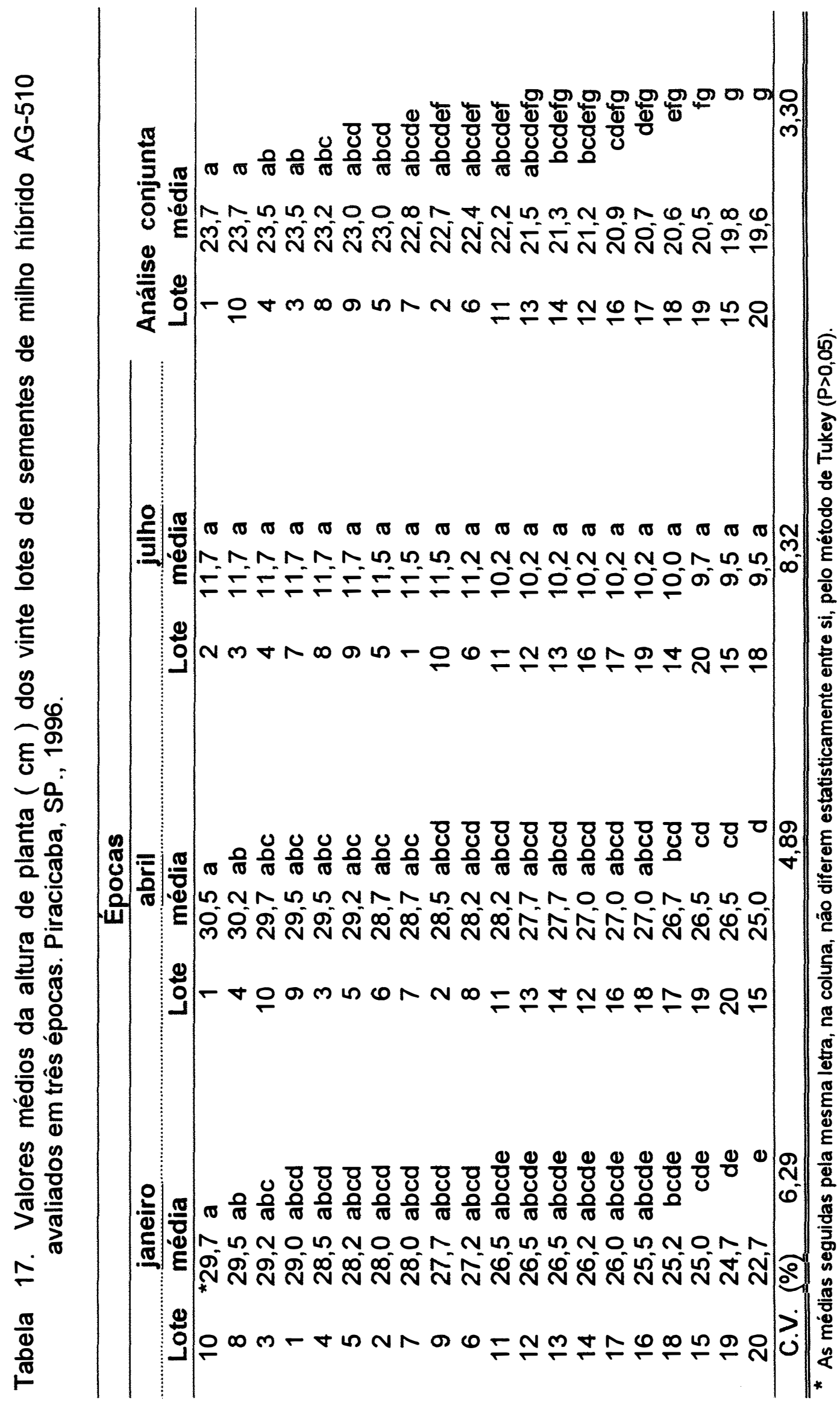


Observou-se que as respostas dos lotes foram semelhantes na primeira e segunda épocas, ficando a maioria no grupo de melhor desempenho. Não obstante, na terceira época o desenvolvimento das plântulas foi reduzido em relação aos casos anteriores, não se verificando diferença significativa entre lotes, certamente devido ao clima reinante na ocasião.

Já na análise conjunta houve uma maior diferenciação, colocando-se no grupo de melhor desempenho os lotes de 1 a 10, incluindo 11 e 13. Por outro lado, os que tiveram a menor altura de plântulas foram os lotes 20 e 15 , seguidos por $19,18,17$ e 16 .

\subsection{Correlações}

As médias gerais de cada lote, obtidas por meio das análises do conjunto de épocas, foram utilizadas para o estudo de correlação linear simples ( Tabela 18 ), com o propósito de se verificar o grau de relacionamento entre os novos testes em estudo e os outros ensaios bem conhecidos.

A precocidade da raiz primaria ( PER ), às temperaturas de 20 e $25^{\circ} \mathrm{C}$, mostraram correlações altamente significativas com os demais dados colhidos. Além da dependência entre si $\left(0,736^{\star \star}\right)$, houve uma forte tendência linear positiva com o TPG, primeira contagem, emergência em areia, teste de frio e emergência no campo. Os valores negativos e significativos de $r$ correspondentes ao número de sementes mortas e ao teste de condutividade elétrica, também se revelam de grande importância. Já O PER a $30^{\circ} \mathrm{C}$ correlacionou-se com menor número de variáveis, porém foi positiva e 
altamente significativa com o teste PER 20 e $25^{\circ} \mathrm{C}$, índice de velocidade de emergência em areia e altura das plântulas.

O TPG e a primeira contagem apresentaram comportamento semelhante entre si e quanto às correlações com as outras características avaliadas. A relação entre estes dois parâmetros alcançou 0 valor de $0,712^{\star \star}$ e $r$ significativo acima de 0,7 com os testes de frio, condutividade elétrica, emergência em campo, PER 20 e $25^{\circ} \mathrm{C}$.

O teste de emergência em areia e o índice de velocidade em areia não se mostraram relacionados entre si pois $\circ r$ obtido não foi significativo. Por outro lado a emergência em areia mostrou correlações altamente significativas com $\circ$ teste de frio, de envelhecimento precoce e condutividade elétrica, acontecendo o inverso com o índice de velocidade em areia.

Além dos casos mencionados, 0 teste de frio se relacionou significativamente com 0 envelhecimento precoce, sementes mortas, condutividade elétrica, emergência no campo e altura das plântulas.

Os resultados obtidos para o teste de envelhecimento precoce, sementes mortas e condutividade elétrica evidenciaram correlação consistênte entre os mesmos. Verificou-se, também, a significativa relação entre a emergência no campo e a altura de plântulas no campo.

No caso da altura das plântulas registraram-se, também, correlações altamente significativas com o TPG e a primeira contagem, porém não houve significância com o teste de emergência em areia, envelhecimento precoce e sementes mortas. 


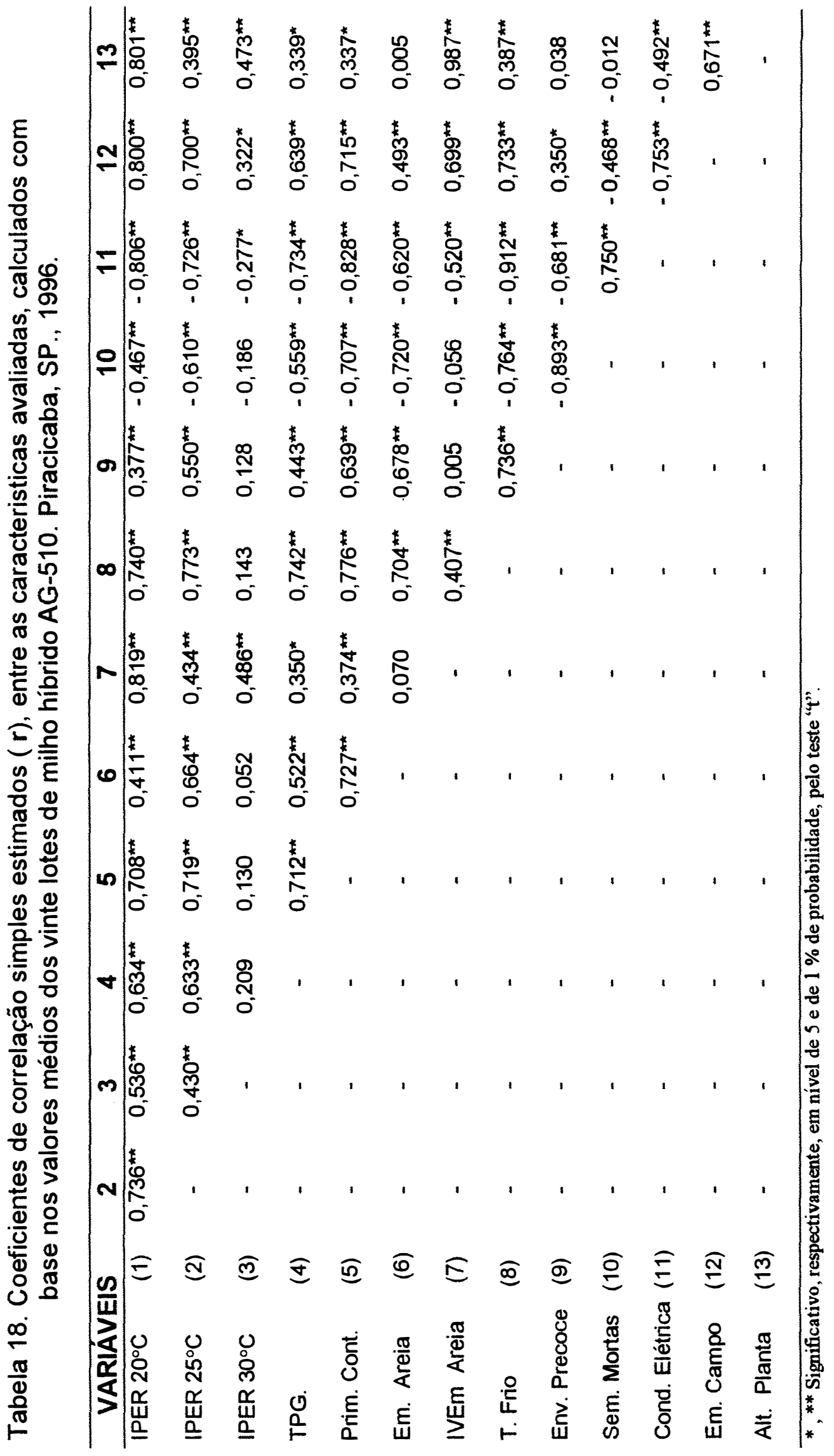




\section{DISCUSSÃO}

O vigor é considerado como um atributo que abrange várias propriedades das sementes como, por exemplo, velocidade de germinação, uniformidade da emergência e desenvolvimento, robustez da plântula etc. Portanto, ao se conduzir pesquisas sobre este atributo é sabido que há necessidade de se controlar ao máximo possivel os fatores que afetam a eficiência e a confiabilidade dos testes, em vista de ser cada vez mais importante dispor de métodos simples, rápidos e padronizados a fim de atender as exigências atuais da agricultura. À medida em que as técnicas de manejo de culturas tornam-se mais sofisticadas, aumentam as necessidades de sementes de qualidade comprovada (Perry, 1984).

Neste sentido, no planejamento deste trabalho, foram adotadas amostras de lotes de sementes de um único hibrido com uniformidade no tamanho e não tratadas com fungicidas para que o efeito de fatores diversos não mascarasse o desempenho do material. Outro parâmetro controlado foi o teor de água das sementes dentro de lotes e entre épocas de avaliação ( Tabela 1). A adoção de três épocas, com certeza, também contribuiu para a intensificação do estudo.

Assim, é provável que o conjunto destes procedimentos tenha permitido, na maioria dos ensaios, manter coeficientes de variação em niveis satisfatórios. Por outro lado, as informações climáticas (Figuras 1 e 2) são de grande apoio para elucidar algumas questões sobre os ensaios que foram conduzidos em condições ambientais. 
Em seguida é apresentada, em primeiro lugar, a discussão dos resultados obtidos sobre o indice de precocidade da emissão de raiz primária. Depois são considerados os outros testes e suas relações com o novo teste PER.

\subsection{Precocidade da emissão de raiz primária.}

De inicio, é interessante destacar os baixos valores dos coeficientes de variação no PER, que são conseqüência de vários aspectos próprios do teste e possivelmente do substrato usado para o melhor fornecimento de umidade. Pode-se dizer também que o processo de avaliação do PER, que implica na retirada das sementes cujas raízes primárias tenham emergido, é muito simples, mas de suma importância por ter seu fundamento na ontogenia da germinação. Esta, na terceira e última fase da embebição, é caracterizada pelo crescimento visível do eixo embrionário (Bewley \& Black, 1985) e é associada a significativos incrementos da taxa de absorção de água e da atividade respiratória, para os quais a radícula em fase de emissão contribui enormemente, destacando-se também que ela se desenvolve antes da parte aérea (Simmons, 1987; Silva, 1989).

Para se administrar água em proporções suficientes e uniformes foram utilizadas 5 folhas de germitest no lugar de 3 como no TPG. Este procedimento mostrou, conforme foi observado, uma resposta favorável. Sabe-se que a adequada disponibilidade de água propicia à semente maior velocidade de embebição (Gulliver \& Heydeker, 1973) e promove a reativação dos sistemas metabólicos que conduzem à expansão e às divisões celulares do embrião (Kermode et al., 1986). 
A recomendação, em relação às temperaturas para se proceder testes de germinação com milho, nas Regras de Analise de Sementes (Brasil, 1992), abrange 20,25 e $30^{\circ} \mathrm{C}$. Na presente pesquisa, se estudou as modalidades de 20,25 e $30^{\circ} \mathrm{C}$, devido ao fato da temperatura ser de considerável importância nos processos do metabolismo, de respiração e de embebição da água (Murphy \& Noland, 1982; Carvalho \& Nakagawa, 1988; Ferreira et al., 1990). Assim sendo, poderia ser verificada uma resposta diferencial entre os lotes em função dessas temperaturas. Neste sentido, observou-se nas determinações realizadas que houve variações entre lotes, provenientes das modalidades estudadas.

O fato da resposta da emissão da raiz primária ter sido acelerada, à medida que se aumentou a temperatura, era de se esperar, pela grande influência que este fator tem sobre a velocidade do processo como sobre a porcentagem de germinação, segundo o indicado por Ferreira et al. (1990). Mas quando se estudou os períodos de avaliação ficou evidente que houve concentração da emissão da raiz primária em duas contagens de cada modalidade (Figura 4).

Segundo Côme \& Tissaoui (1973), quanto mais baixa a temperatura para germinação maior é a quantidade de oxigênio disponivel ao embrião, porém o metabolismo respiratório é incipiente e em conseqüência mais lenta é a velocidade de germinação; por outro lado, em temperaturas elevadas, menor é a quantidade de oxigênio disponivel uma vez que o metabolismo respiratório aumenta. Em vista dessas alternativas acredita-se que seja possivel definir a temperatura mais adequada para se conduzir o PER. 
Como foi apresentado nos resultados, o novo teste mostrou-se satisfatório, nas três épocas em que foi empregado, para classificar com consistência os diferentes materiais utilizados na pesquisa, destacando-se os lotes 4 e 5 como os mais vigorosos e o 18, 19 e 20 como os mais fracos, no caso do teste PER a 20 e $25^{\circ} \mathrm{C}$. Deste modo, estas duas modalidades, em princípio, revelaram sua eficiência, não só pela capacidade de separar lotes como, também, pela consistência de seus resultados. Quanto a este teste PER- $25^{\circ} \mathrm{C}$, Toledo et al. (1995) já haviam demostrado suas virtudes em trabalho realizado com a mesma espécie (Zea mays L.). Todavia, o PER$30^{\circ} \mathrm{C}$, embora tenha indicado diferenças entre os lotes, elas não acompanharam aquelas observadas nos casos anteriores.

\subsection{Outros testes}

\subsubsection{Teste padrão de germinação}

O TPG, amplamente utilizado nos laboratórios, é o método mais importante para se avaliar a qualidade fisiológica de um lote de sementes.

Tem como principal objetivo detectar a mais elevada porcentagem possivel de plântulas normais da amostra, uma vez que apresenta um período de execução prolongado e oferece ótimas condiçöes para a germinação (Delouche, 1981).

Nesta pesquisa, todo material foi submetido a esse teste, nas três épocas programadas e os resultados permitiram verificar que a maioria dos 
lotes era de alta qualidade, conforme os padrões da Comissão Estadual de Sementes e Mudas (CESM) de 1996. Esta resposta, que persistiu durante as épocas, juntamente com os baixos coeficientes de variação, mostraram que tais ensaios foram conduzidos satisfatoriamente.

Conforme já foi mencionado, o TPG revelou diferenças significativas entre os lotes como ocorreu com o PER, porém aparentemente com menor intensidade. Embora não seja um método próprio para a avaliação do vigor, a sua utilização neste trabalho reveste-se de muita importância, pois além de caracterizar os lotes é da mais alta confiabilidade.

\subsubsection{Primeira contagem de germinação}

O teste da primeira contagem de germinação caracteriza-se por ser relativamente rápido e avaliar as diferenças fisiológicas dos lotes com base na velocidade de germinação (AOSA, 1983; Marcos Filho et al 1987). Não obstante, neste trabalho, os resultados obtidos indicaram pouca ou nenhuma diferença na avaliação dos lotes por este teste e pelo TPG. Esse fato pode ser atribuído ao material genético usado, o híbrido AG- 510 , que teve sua máxima taxa de germinação na primeira contagem do TPG, sob condições ótimas de umidade e temperatura.

Para explicar a diferença encontrada entre os lotes encontrada, pode-se apontar os estudos sobre o processo de deterioração conduzidos por McDonald Jr. (1975) e Matthews (1985) indicando a queda na velocidade de germinação como evidência da perda de vigor das sementes. Portanto, as amostras que se desenvolvem com maior rapidez apresentam valores mais elevados na primeira contagem. 


\subsubsection{Teste de emergência das plântulas em areia}

Em relação a emergência em areia constatou-se que o substrato usado e as condições ambientais favoreceram a condução do teste de maneira satisfatória visando encontrar informaçōes sobre o material usado. Neste sentido, ao se estudar os dados obtidos dentro de épocas e na análise conjunta, observou-se certa concordância com os outros testes já discutidos. Assim é que os lotes 4, 5 e 10 se mostraram, na maioria dos casos, como os melhores e os lotes 18, 19 e 20 como os mais fracos. Apesar deste ensaio ser realizado em condições ambientais não controladas (Figura 2) o efeito de lotes não foi mascarado. Houve, todavia, atraso na emergência na terceira época, fato este que exigiu o reumedecimento do substrato, a fim de garantir para as sementes a quantidade de água necessária para sua emergência, em vista de ser a água um fator determinante para que elas iniciem ou continuem o processo de germinação e se desenvolvam normalmente (Carvalho \& Nakagawa, 1988).

\subsubsection{Indice de velocidade de emergência em areia}

À semelhança do caso anterior, o índice de velocidade de emergência em areia foi eficiente para destacar grupos de lotes e fornecer resultados consistentes entre épocas, embora na terceira, as baixas temperaturas durante o mês de julho (Figura 2), atrasassem a emergência de plântulas até 0 oitavo dia. Em estudos sobre o efeito da temperatura na emergência de plântulas de soja, Matthews \& Hayes (1982) observaram que o número de dias necessários para obter $50 \%$ de emergência foi de 8 dias a $13^{\circ} \mathrm{C}$. Em milho, Hope \& Maari (1994) obtiveram períodos médios de 3,8 e 22 dias para a produção de $1 \mathrm{~cm}$ de coleoptilo às temperaturas de 25 e $11^{\circ} \mathrm{C}$, 
respectivamente. Entretanto, segundo Kamaha \& Maguire (1992), em sementes de trigo, temperaturas inferiores a $17^{\circ} \mathrm{C}$ provocaram queda considerável nos processos biológicos da germinação, sendo que a $20^{\circ} \mathrm{C}$ este cereal mostra boa resposta a emergência de plântulas.

\subsubsection{Teste de frio com solo}

As condições oferecidas a esta avaliação foram consideradas adequadas para a diferenciação da qualidade dos lotes tendo em vista a consistência revelada pelos resultados na separação dos lotes nas épocas, sendo esta resposta confirmada pela análise conjunta. Neste sentido, Fratin (1987) observou, também, que o teste de frio revelou maior sensibilidade para definir a qualidade de lotes, em relação a outros métodos usados.

Tekrony (1983) e Nijenstein (1988), entre outros, relataram que este teste é amplamente usado por empresas produtoras de sementes, em programas de controle de qualidade, devido a sua eficiência para avaliar o vigor.

Segundo Grabe (1968), neste caso, em que se está avaliando a resposta ao estresse de frio, cabe assinalar a conveniência de se quantificar a boa qualidade dos lotes, em termos de vigor, na base mínima de 70 a $85 \%$ de plântulas normais. Assim, aplicando-se o critério indicado na análise conjunta dos dados, onde a análise estatística mostrou como melhores os lotes de 1 a 10, deve-se incluir nesse grupo o 11, 12 e 13. É interessante destacar aqui que estes últimos materiais tiveram bom comportamento no PER a $30^{\circ} \mathrm{C}$. 


\subsubsection{Teste de envelhecimento precoce}

Baseia-se no fato de que sementes colocadas em condições estressantes de temperatura e umidade relativa do ar, por um período de tempo pré-estabelecido, tem rápido declínio na germinação (Delouche \& Baskin, 1973), devido ao efeito de mudanças na integridade das membranas (Basavarajappa et al 1991). Em termos gerais, mostrou-se ele eficiente na estratificação do material utilizado neste trabalho, mas em relação ao teste de frio, foi menos consistente ao apresentar mais variabilidade dos lotes nas épocas. Além disso mostrou coeficientes de variação mais elevados do que nos outros casos. De fato, Delouche (1976) indicou diversas causas que podem contribuir para a falta de consistência de resultados. Acredita-se que essas razões poderiam ser controladas; por exemplo, se tem resposta ao efeito do fungicida em diferentes espécies (Marcos Filho \& Shioga, 1981; Alizaga et al.; 1990 Lovato \& Cagalli, 1992; Shekaramurthy et al., 1994), umidade inicial das sementes (Tao, 1979), período de exposição no BOD ( Fratin, 1987; Dias \& Barros, 1995), o uso do gerbox e a importância da distribuição das sementes em uma única camada (McDonald \& Phaneendranath, 1978), a quantidade de água no fundo do gerbox (Tao, 1979), o número e posicionamento das caixas por prateleira (Tomes et al 1988). Assim, apesar dos cuidados na condução dos ensaios e na avaliação dos resultados, a relativa elevação dos coeficientes de variação, sugere que ainda faltam alguns condições próprias do teste que precisam ser estudadas em detalhe. Também Wilson \& Trawatha (1991) encontraram dificuldades para reproduzir a técnica usada de envelhecimento precoce em milho doce. Delouche \& Baskin (1973), Krzyzanowski \& Miranda (1990), em estudos sobre envelhecimento precoce de sementes, observaram que a reprodutividade dos resultados do teste depende da precisão na calibragem da temperatura dos equipamentos usados, tanto para envelhecer as sementes como no teste de germinação, e da contaminação por fungos na superfície e no interior das sementes. 


\subsubsection{Teste de condutividade elétrica}

Este teve início com estudos de sementes de leguminosas, como ervilha ( Bradnock, 1968 ; Bedford, 1974 ) e soja (Tao, 1978). Baseia-se no princípio de que sementes de baixo vigor, quando emersas em água, liberam maiores quantidades de eletrólitos do que as vigorosas devido à perda da integridade das membranas celulares (Matthews \& Powell, 1981; Hampton \& Coolbear, 1990). Nesta pesquisa, o teste forneceu resultados consistentes em relação à estratificação relativa as categorias de vigor. Tal evidência vem reforçar as respostas obtidas por Fratin (1987) que observou certa consistência nos resultados em seu trabalho. Assim, Herter \& Burris (1989), ao examinarem a condutividade elétrica de sementes individuais em relação à germinação e o crescimento de plântulas, revelaram que o método foi eficiente para o descarte de lotes inferiores. De acordo, com as observações em algumas pesquisas feitas em milho doce, este teste apresentou tremendas vantagens de simplicidade e rapidez ( Waters \& Blanchette,1983; Wann, 1986; Schmidt \& Tracy, 1988; Wilson \& Trawatha, 1991; Parera et al., 1995 ). Acredita-se, porém, que seja conveniente continuar os estudos sobre a temperatura de embebição e critérios de interpretação dos resultados objetivando a padronização do teste.

\subsubsection{Teste de emergência de plântulas em campo}

Quanto a emergência das plântulas em campo pode-se dizer que houve uma tendência similar à observada nos testes de germinação, quando as condições do clima foram razoavelmente satisfatórias ( Figura 1). Assim, nas 
duas primeiras épocas de avaliação, os lotes identificados como de alta e baixa qualidade em condições de laboratório, tiveram comportamento semelhante no campo. Este resultado confirma o comentário de Carvalho \& Nakagawa ( 1988 ) ao afirmarem que quando as condições de campo são favoráveis, os resultados do TPG apresentam alta relação com a emergência no campo. Porém, quando o teste de campo foi conduzido na época fria do ano (mês de julho) foi evidente que as baixas temperaturas exerceram influência no potencial de desempenho das sementes viáveis, refletindo-se em falhas na emergência o que reduziu o «stand" em todos os lotes.

Da mesma forma, em estudos feitos sobre fatores associados com a qualidade e vigor de milho, quando semeados em solos frios, Wann (1986)

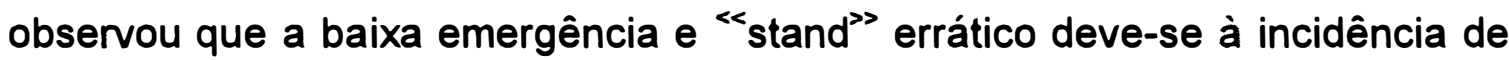
danos ou doenças da cariopse, que têm estreita relação com o vigor das plântulas. Também, Bruggink et al. (1991) reportaram que temperaturas na faixa de 13,5 a $15,5^{\circ} \mathrm{C}$, foram responsáveis pela redução da porcentagem de plântulas de milho semeado no solo.

\subsubsection{Altura de plântula}

Este parâmetro, avaliado após da porcentagem de emergência em campo, mostrou certa sensibilidade para expressar o vigor de lotes de sementes. Assim, quando as condições climáticas foram favoráveis, as

plântulas tiveram crescimento rápido e tamanho pouco discrepante. Mas quando os materiais foram expostos a baixas temperaturas a reação foi tão negativa que o desenvolvimento das plântulas diminuiu de tal sorte que não houve diferenças entre os lotes. A este respeito, pode-se dizer que a sensibilidade observada dos materiais em condições frias é justificável porque 
o híbrido AG - 510, do qual se derivaram os lotes em ensaio, foi produzido para clima tropical e subtropical, que são as mais predominantes no Brasil; portanto, sob condições frias e úmidas, este material não teve capacidade de desenvolver normalmente. Mock \& Eberhart (1972) apresentaram evidências de que nas populações de milho há sistemas genéticos que condicionam a tolerância ao frio e que são independentes daqueles que controlam a emergência e a maturidade em condições normais de plantio; assim, indicaram que é provável que a tolerância dos genótipos de milho a condições adversas seja conseqüência de sua adaptação às regiōes frias.

\subsection{Correlações}

Para se determinar as condições fisiológicas das sementes destinadas às grandes e modernas lavouras de milho, tem-se desenvolvido testes que além de estimar o poder germinativo desse material avalia, também, o seu vigor, mormente a sua capacidade de produzir plântulas normais no campo, comforme já relataram Matthews (1981) e Perry (1984). Neste trabalho onde se estudou o comportamento de novos testes de vigor, foi realizada a comparação destes métodos com outros métodos tradicionais e com a emergência de campo para verificar o grau de relacionamento entre os mesmos. Assim, os resultados do PER, às temperaturas de 20 e $25^{\circ} \mathrm{C}$, evidenciaram uma correlação significativa com a maioria dos testes, sendo bem definidas com a primeira contagem do TPG, o teste de frio, a condutividade elétrica e a emergência em campo, onde os valores de $r$ foram significativos e maiores que 0,70 , salvo num caso. Esses resultados indicaram que tais métodos se eqüivaleram, ou seja, se igualaram. Não se pode, porém, desprezar as outras correlações significativas, pois também corroboram a eficiência do PER a 20 e $25^{\circ} \mathrm{C}$. Já o novo teste a $30^{\circ} \mathrm{C}$ não mostrou as mesmas virtudes. Cabe destacar, 
ainda, que o PER- $20^{\circ} \mathrm{C}$ revelou-se mais eficiente que o PER- $25^{\circ} \mathrm{C}$. Também, pode-se afirmar que ambos testes foram melhores para refletir o desempenho de campo que o TPG. Por outro lado, o fato do teste de frio e de condutividade elétrica apresentarem uma correlação alta e significativa entre si $(r=-0,92)$ indicou que os lotes que tiveram melhor desempenho sob condições de estresse fisiológico pelo frio responderam com baixos índices de condutividade elétrica. Ambos mostraram, também, valores altos de correlação com emergência de campo. Para o teste de frio, Martin et al. (1988) obtiveram alta correlação com campo $(r=0,74)$, sendo superior aos outros por eles avaliados. Bruggink et al. (1991) também, observaram que o teste de frio, sem tratamento fungicida, se correlacionou melhor com o de campo $(r=0,76$ a 0,92$)$ que com sementes tratadas ( $r=0,63$ a 0,77 ). No caso do método de condutividade elétrica a relação significativa obtida na presente pesquisa também está de acordo com a resposta encontrada em milho doce por Walters \& Blanchete (1983), com r =0,77 a 0,80 e Wilson \& Trawatha (1991), com $r=0,85$ a 0,88.

\subsection{Considerações gerais}

Neste trabalho foram utilizados vários testes de vigor como referência para se pesquisar em torno do método de precocidade da emissão da raiz primária ( PER ), proposto por Toledo et al. (1995). Ficou evidente que este teste apresentou regularidade e consistência de resultados, nas três épocas nas quais os ensaios foram conduzidos, e correlação significativa com outros métodos já mencionados.

Além disso, acredita-se que seja relevante salientar alguns aspectos relacionados com a nova metodologia e com os que vem sendo usados. Assim, 
para se chegar ao PER foram empregados procedimentos semelhantes aos do TPG (Brasil, 1992) e dos ensaios de velocidade de germinação (Maguire, 1962). Não houve, portanto, necessidade de acrescentar novos materiais, equipamentos e instalações, fato este de significativa importância. $O$ dispêndio de tempo foi também menor doque o necessário para a primeira contagem do TPG, mesmo no caso do PER a $20^{\circ} \mathrm{C}$ que consumiu 3,5 dias para se chegar aos dados finais (Figura 4). Esta característica, em termos práticos e econômicos, tem grande significado, em vista do elevado número de ensaios que são conduzidos nos laboratórios de firmas comerciais e de instituições de pesquisa.

A interpretação dos testes, em geral, tem sido considerada como um sério problema a fim de se obter precisão e reprodutibidade dos resultados, principalmente quando não se dispõe de pessoal bem treinado para realizar a adequada classificação das plântulas no caso do TPG (Delouche, 1981) e a seleção de sementes sem possíveis danos nos tegumentos (Tao, 1980; Marcos Filho et al., 1987; Vieira, 1994). No caso do teste PER, a avaliação da emissão da raiz primária foi considerada bem simples e objetiva.

Deve-se considerar, ainda, que há testes que exigem treinamento intensivo de pessoal, como no caso do tetrazólio (Marcos Filho et al., 1987) e da condutividade elétrica (McDonald Jr. \& Wilson, 1979; Sterre et al., 1981; Loeffler,1988); o que não ocorre com o PER.

Sendo assim, acredita-se que as boas qualidades apresentadas pelo PER justifiquem outros estudos visando o seu aprimoramento, sua padronização e a extensão de sua aplicação em sementes de outras espécies cultivadas. 


\section{CONCLUSÃO}

Os resultados obtidos do presente trabalho permitiram concluir que a precocidade de emissão da raiz primária, a 20 e $25^{\circ} \mathrm{C}$, pode ser de grande utilidade para avaliação do vigor de sementes de milho (Zea mays L.). 


\section{REFERÊNCIAS BIBLIOGRÁFICAS}

ABDUL - BAKI, A. A. Biochemical aspects of seed vigor. HortScience, v.15, n.6, p.765-771, 1980.

ALIZAGA, R.L.; MELLO,V.D.C.; SANTOS, D.S.B.; IRIGON, D.L. Avaliação de testes de vigor em sementes de feijäo e suas relações com emergência a campo. Revista Brasileira de Sementes, v.12, n.2, p.44-58, 1990.

ASSOCIATION OF OFFICIAL SEED ANALYSTS. Seed vigor testing handbook, AOSA 1983. 88p. (Handbook on seed testing. Contribution, 32).

BARLA- SZABÓ, G.; DOLINKA, B. Complex stressing vigor test: a new method for weat and maize seed. Seed Science and Technology, v.16, p.63-73, 1988.

BASAVARAJAPPA, B.S.; SHETTY, H.S.; PRAKASH, H.S. Membrane deterioration and other biochemical changes associate with accelerated ageing of maize seed. Seed Science and Technology, v.19, n.2, p.279-286, 1991.

BAUER, A.; BLACK, A. L. Sprouting in intact mature spikes of hard red spring wheat. Agronomy Journal, v.75, n.6, p.1016-1022, 1983.

BEDFORD, L.V. Conductivity test in comercial and hand hardvested seed pea cultivars and their relation to field establishment. Seed Science Technology, v.2, n.3, p.323-325, 1974.

BEKENDAM, J.; KRAAK, H.L.; VOS, J. Studies on field emergence and vigour of onion, sugar beet, flax and maize seed. Acta Horticulture, v.215, p.8389, 1987.

BERLYN, G.P. Seed biology. New York: Academic Press, 1972. v. 2, p. 223312. 
BEWLEY, J.D.; BLACK, M. Seed: physiology of development and germination. New York, Plenum Press, 1985. 367p.

BRADNOCK, W.T. Method for predicting field emergence of peas. Proceedings of the Association of Official Seed Analysts, v.58, p.70-75, 1968.

BRASIL. Ministério da Agricultura e Reforma Agrária. Regras para análise de sementes. Brasilia, 1992. $365 \mathrm{p}$.

BRUGGINK, H.; KRAAK, H.L.; BEKENDAM, J. Some factors affecting maize (Zea mays L.) cold test results. Seed Science and Technology, v.19, n.1, p.15-23, 1991.

BRUGGINK, H.; KRAAK, H. L.; DIJKEMA, M.H.G.E.; BEKENDAM, J. Some factors influencing electrolyte leakage from maize (Zea mays L.) kernels. Seed Science Research, v.1, n.1, p.15-20, 1992.

BURRIS, J.S.; NAVRATIL, R.J. Relationship between laboratory cold test method and field emergence in maize imbreds. Agronomy Journal, v.71, n.6, p.985-988, 1979.

CARVALHO, N.M.; NAKAGAWA, J. Sementes: ciência, tecnología e produção. 3. ed. Campinas: Fundação Cargill, 1988. 429 p.

CHASTAIN T. G.; WASRD, K. J.; WYSOCKI D.J. Stand establishment responses of soft white winter wheat to seedbed residue and seed size. Crop Science, v.35, p. 213-218, 1995.

CICERO, S.M.; VIEIRA, S.D. Teste de frio. In: VIEIRA, R.D.; CARVALHO, N.M. (Ed.) Testes de vigor em sementes. Jaboticabal: FUNEP, 1994. p.151-164.

CICERO, S.M.; CHAMMA, H.M.C.P.; MORAES, M.H.D. Tratamento fungicida em sementes de milho. Piracicaba: ESALQ, Depto. de Agricultura, 1989. $14 \mathrm{p}$.

CÔME, D.; TISSAOUI, J. Interrelated effects of imbibtion, temperature and oxigen on seed germination. In: HEYDECKER, W. Seed ecology. Nottingham, Pennsylvania State, University Press, 1973. p.157-168. 
COSTA, A. A.; SILVA, R. F.; SEDIYAMA, T.; SEDIYAMA C. S.; MONTEIRO P.M.F.O. Teste de lixiviação de solutos na avaliação da capacidade germinativa de sementes de soja. In: SEMINÁRIO NACIONAL DE PESQUISA DE SOJA, 3., Campinas, 1987. Anais. Londrina: EMBRAPA, CNPSO, 1984. p.958-966.

DADLANI, M.; AGRAWAL, P.K. Factors influencing leaching of sugar and electrolytes from carrots and okra seeds. Scientia Horticulturae, v.19, p.3944, 1983.

DELOUCHE, J. C. Seed deterioration. Seed World, v.92, n.4, p.14-15, 1963.

DELOUCHE, J. C.; BASKIN, C. C. Accelerated aging technique for predicting the relative storability of seed lots. Seed Science and Technology, v.1, n.2, p.427-452. 1973.

DELOUCHE, J. C. Standardization of vigor tests. Journal Seed Technology, v.1, n.2, p.75-85, 1976.

DELOUCHE, J. C. Metodologia de pesquisa de sementes III: vigor, envigoramento e desempenho no campo. Revista Brasileira de Sementes, v.3, n.2, p.57-64, 1981.

DESWAL, D.P.; SHEORAM I.S. A simple method for seed leakage measurement: applicable to single seed of any size. Seed Science and Technology, v.21, p.179-185, 1993.

DIAS, M. C. L. de L.; BARROS, A. S. do R. Metodologias dos testes aplicados no controle de qualidade de sementes de milho. Londrina: IAPAR, 1995. 43 p. (IAPAR Circular, 88).

EDJE, D. T.; BURRIS, J. S. Seedling vigor in soybeans. Proceedings of the Association of Official Seed Analysts, v.60, p.149-157, 1970.

ELLIS, R.H.; ROBERTS, E.H. Towards a rational basis for testing seed quality. In: HEBBLETHWAITE, P.D., (Ed.) Seed production. London: Butterworth, 1980. p.605-635.

FERNANDEZ , G.; JOHNSTON, $M$. Vigour tests for grain legumes. In: INTERNATIONAL SEED TESTING CONGRESS, 23., Buenos Aires, 1992, Abstracts. Buenos Aires: ISTA, 1992. n.2, p.10-11. 
FERREIRA, F.R.; BRANCO, S.; SADER, R. Germinação de sementes de uva japoneza e beribá. Revista Brasileira de Sementes, v.12, n.1, p.73-81, 1990.

FRANCIS, A.; COOLBEAR, P. Change in the fatty acid content of the polar lipid fraction of tomato seed induced by ageing and/or subsequent low temperature presowing treatment. Seed Science and Technology, v.16, p.87-95, 1988.

FRATIN, P. Comparação entre métodos para avaliação da qualidade fisiológica de sementes de milho (Zea mays L.). Piracicaba, 1987. $191 \mathrm{p}$. Disertação (Mestrado). Escola Superior de Agricultura "Luiz de Queiroz", Universidade de São Paulo.

GOMES, F.P. Curso de estatística experimental. 8.ed. São Paulo: Livraria Nobel, 1978. $430 \mathrm{p}$.

GRABE, D.F. Quality control in seed production. In: SHORT COURSE FOR SEEDMEN. Mississipi State, 1968. Proceedings Mississipi State University, $7 p$.

GRABLE, A. R.; DANIELSON, R. E. Effect of $\mathrm{CO} 2,02$ and soil moisture suction on germination of corn and soybeans. Soil Science of the Society of American Proceedings, v.29, p.12-18, 1965.

GULLIVER, R. L.; HEYDECKER, W. Establishment of seedling in a changeable enviroment. In: HEYDECKER, W. (Ed.) Seed ecology Nottingham, Pensylvania State University Press, 1973. p.433-462.

GURMU, M.; NAYLOR, R. E. L. Effects of low water availability on germination of two sorghum cultivars. Seed Science and Technology, v.19, p.373-383, 1991.

HABER, A. H.; LUIPPOLD, H. J. Separation of mechanisms initiating cell division and cell expansion in lettuce germination. Plant Physiology, v.35, n.2, p.168-173, 1960.

HAMPTON, J.G.; COOLBEAR, P. Potencial versus actual seed perfomance. Can vigour testing provide an answer? Seed Science and Technology, v.18, n.2, p.215-228, 1990.

HAMPTON J.C; JOHNSTORE, K. A.; EUA-UMPON V. Bulk conductivity test variables for mungbean, soybean and frenchbean seed lots, Seed Science and Technology, v.20, p.677-686, 1992. 
HARMAN, G. E. Mechanisms of seed infection and pathogenesis. In: Deterioration mechanism in seeds. Phytopathology, v.73, n.2, p.326-329, 1983.

HEGARTY, T. W. Seed activation and seed germination under moisture stress. New Phytologist, v.78, n.3, p. 349-359, 1977.

HEGARTY, T. W. The physiology of seed hydration and dehydration, and relation between water stress and the control of germination: a review. Plant Cell and Environment, v.1, p.101-119, 1978.

HERTER, V.; BURRIS, J. S. Evaluating drying injury on corn seed with a condutivity test. Seed Science and Technology, v.17, n.3, p.625-638, 1989.

HOPE, H.J.; MAARI, R. Measurement of maize cold tolerance during germination. Seed Science and Technology, v.22, p.69-77, 1994.

KAMAHA, C.; MAGUIRE, J.D. Effect of temperature on germination of six winter wheat cultivars. Seed Science and Technology, v.20, p.181-185, 1992.

KERMODE, A. R.; BEWLEY, J.D.; DASGUPTA, J.; MISRA, S. The transition from seed development to germination: a key role for desiccation? HortScience, v.21, n.5, p.1113-1117, 1986.

KHAN, A.A. The physiology and biochemistry of seed development and germination. New York: Elsevier 1982. 447p.

KRZYZANOWSKI, F. C.; MIRANDA, Z. F. S. Relatório do comitê de vigor da ABRATES. Informativo ABRATES, v.1, n.1, p.7-25, 1990.

KUO, W. H. J. Delayed-permeability of soybean seeds: characteristics and screening methodology. Seed Science and Technology, v.17, n.1, p.131142, 1989.

LIN, S.S. Efeito do período de armazenamento na lixiviação eletrolítica dos solutos celulares e qualidade fisiológica de sementes de milho (Zea mays L.) e feijão (Phaseolus vulgaris L.), Revista Brasileira de Sementes, v.10, n.3, p.59-67, 1988.

LOEFFLER, T.M.; MEYER, J. L.; BURRIS, J. S. Comparision of two cold test procedures for use in maize drying studies. Seed Science and Technology, v.13, n.3, p.653-658, 1985. 
LOEFFLER. T.M.; TEKRONY, D.M.; EGLI, D.B. The bulk condutivity test as an indicator of soybean seed quality. Jornal Seed and Technology, v.12, n.1, p.37-52, 1988.

LOVATO, A.; CAGALLI, S. Sugar beet (Beta vulgaris L.) seed vigour compared in laboratory and field tests,. Seed Science and Technology, v.21, p.61-67, 1992.

MAGUIRE, J.D. Speed of germination-aid in selection and evaluation for seedling emergence and vigor. Crop Science, v.2, n.1, p.176-177, 1962.

McDONALD Jr., M.B. A review and evaluation of seed vigor tests. Proceedings of the Association of Official Seed Analysts, v.65, p.109139, 1975.

McDONALD Jr., M.B.; PHANEENDRANATH, B.R. A modified accelerated aging seed vigor test for soybean. Journal Seed Technology, v.3, n.1, p.27-37, 1978.

MCDONALD Jr., M.B.; WILSON, D.O. An assessment of the standarization and ability of the ASA-610 to rapidly predict soybean germination. Journal Seed Technology, v.4, n.2, p.1-11, 1979.

McDONALD Jr., M.B.; WILSON, D.O. ASA-610 ability to detect changes in soybean seed quality. J. Seed Technol., v.5,n.1, p.56-66, 1980.

MARCOS FILHO, J. Teste de envelhecimento acelerado. In: VIEIRA, R.D.; CARVALHO, N.M., (Ed.) Testes de vigor em sementes. Jaboticabal: FUNEP, 1994. p.133-149.

MARCOS FILHO, J.; CICERO, S.M.; SILVA, W.R da. Avaliação da qualidade das sementes. Piracicaba: FEALQ, 1987. $230 \mathrm{p}$.

MARCOS FILHO, J.; CICERO, S.M.; TOLEDO, F.F. de. Manual de análise de sementes. Piracicaba: FEALQ, 1985. 112 p.

MARCOS FILHO, J.; SHIOGA, P.S Tratamento fungicida de sementes de soja no teste de envelhecimento rápido. Revista. Agricola, v.56, n.3, p.163-172, 1981. 
MARCOS FILHO, J.; SILVA, W.R da.; NOVEMBRE, A.D.C.; CHAMMA, H.M.C.P. Estudo comparativo de métodos para avaliação da qualidade fisiológica de sementes de soja com ênfase no teste de condutividade elétrica. Pesquisa Agropecuaria Brasileira, v.25, n.12, p.1805-1815, 1990.

MARTIN, B.A.;SMITH, O.S.; O'NEIL, M. Relationships between laboratory germination and field emergence of maize inbreds. Crop Science, v.28, p.801-805, 1988.

MATTHEWS, D. J.; HAYES, P. Effect of temperature on germination and emergence of six cultivars of soybean (Glycine max.). Seed Science and Technology, v.10, p.547-555, 1982.

MATTHEWS, S. Evaluation of techniques for germination and vigour studies, Seed Science and Technology, v.9, p.543-551, 1981.

MATTHEWS, S. Physiology of seed ageing. Outlook on Agriculture, v.14, p.89-94, 1985.

MATTHEWS, S.; BRADNOCK, W.T. Relationship between seed exudation and field emergence in peas and french beans. Horticulture Research, v.8, p.89-93, 1968

MATTHEWS, S.; POWELL, A.A. Electrical condutivity test. In: PERRY, D.A (Ed). Handbook of vigour test methods. Zurich: ISTA, 1981. p37-42.

METIEVER, J.R. Dormência e germinação. In: FERRI, M.G., (Coord.) Fisiológia vegetal. São Paulo: EPU/EDUSP, 1979. v.2, p.343-392.

MOCK, J.J.; EBERHART, S.A. Cold tolerance in adapted maize populations Crop Science, v.12, p.466-469, 1972.

MURPHY, J.B.; NOLAND, T.L. Temperature effects on seed imbibition and leakage mediated by viscosity and membranes. Plant Physiology, v.69, n.2, p.428-431, 1982

NAKAGAWA, J. Testes de vigor baseados na avaliação das plântulas. In: VIEIRA, R.D. \& CARVALHO, N.M. (Ed.) Testes de vigor em sementes. Jaboticabal, FUNEP, 1994. p.49-86.

NIJENSTEIN, J.H. Effects of some factors influencing cold test germination of maize. Seed Science and Technology, v.12, n.1, p.313-326, 1985. 
NIJENSTEIN, J.H. Effects of soil moisture content and crop rotation on cold test germination of corn (Zea mays L.). Journal Seed and Technology, v.12, n.1, p.99-106, 1988.

NORTON, C.R. Germination under flooding: metabolic implications and alleviation of injury. HortScience, v.21, n.5, p.1123-1125, 1986.

OLIVEIRA, M de A.; MATTHEWS, S.; POWELL, A.A. The role of split seed coats in determining seed vigour in commercial seed lots of soybean as measured by the electrical condutivity test. Seed Science and Technology, v.12, p.659-668, 1984.

OMETTO, J.C. Registros e estimativas dos parâmetros meteorológicos da região de Piracicaba, SP. Piracicaba: FEALQ, 1991. 76p.

PARERA, C.A.; CANTLIFFE, D.J.; STOFFELLA, P.J.; SCULLY, B.T. Field emergence of shrunken-2 corn predicted by single - and multiple- vigor laboratory tests Journal of the American Society of Horticulture Science, v.120, n.1, p.128-132, 1995.

PARRISH, D.A.; LEOPOLD, A.C. On the mechanism of aging in soybean seeds. Plant Physiology, v.61, p.365-368, 1978.

PERRY, D.A. The concept of seed vigour and its relevance to seed production. In: HEBBLETHWAITE, P. D., (Ed.). Seed production. London: Butterworths, 1980. p.585-591.

PERRY, D.A. Report of the vigor test committee 1977-1980. Seed Science and Technology, v.9, n.1, p.115-128, 1981.

PERRY, D.A. Comentary on ISTA vigour test committe colaborative trials. Seed Science and Technology, v.12, p.301-308, 1984.

PESKE, S.T.; DELOUCHE, J.C. Semeadura de soja em condições de baixa umidade do solo. Pesquisa Agropecuaria Brasileira, v.20, n.1, p.69-85, 1985.

POPINIGIS, F. Fisiologia de sementes. Brasília: MAAGLIPAN, 1977. 290p.

POWELL, A.A Cell membranes and seed leachate condutivity in relation to the quality of seed for sowing. Journal Seed Technology, v.10, n.2, p.81-100, 1986. 
RAM, C.; KUMARI, P; SINGH, O.; SARDANA, R.K. Relationship between seed vigour tests and field emergence in chickpea. Seed Science and Technology, v.17, p.169-173, 1989.

SCHMIDT, D.H.: TRACY, W.F. Endosperm type, inbred background, and leakage of seed electrolytes during imbibition in sweet corn. Journal of the American Society of Horticulture Science, v.113, n.2, p.269-272, 1988.

SHEKARAMURTHY, S.; KESHAV, L.P.; SUDHEER, A,S.; PRAKASH, H.S.; SHETTY, H.S. Effect of thiram treatment on sorghum seed quality in relation to accelerated ageing. Seed Science and Technology, v.22, p.607-617, 1994.

SILVA, W.R. da. Relaçōes entre a disponibilidade de água, tratamento fungicida e germinação de sementes de milho (Zea mays $L$ ). Piracicaba, 1989. 113p. Tese (Doutorado). Escola Superior de Agricultura "Luiz de Queiroz", Universidade de São Paulo.

SIMON, E.W. Early events in germination. In: MURRAY, D.R. (Ed.) Seed physiology. New York: Academic Press, 1984. v.2, p.77-116.

SIMMONS, S.R. Growth, development and physiology. In. HEYNE, E. G., (Ed.), Wheat and wheat improvement. Madison: American Society of Agronomy, 1987. p.115-150.

SOUZA, J. de. Sementes: produção, distribuição e comercialização. In: OSUNA, J.A.; MORO, J.R. (Eds.) Produção e melhoramento do milho. Jaboticabal: FUNEP, 1995. p.99-108.

STEERE, W.C.; LEVENGOOD, W.C.; BONDIE, J.M. An electronic analyser for evaluating seed germination and vigour. Seed Science and Tecnology, v.9, p.567-576, 1981.

STYLER, R.C.; CANTLIFFE, D.J. Changes in seed structure and composition during development and their effects on leakage in two endosperm mutants of sweet corn. Journal of the American Societyof Horticulture Science, v.108, n.5, p.721-728, 1983.

SUNG, F.J.M.; CHANG, Y.H. Biochemical activities associated with priming of sweet corn seeds to improve vigor. Seed Science Technology, v.21, p.97105, 1993.

TAKAYANAGI, K.; MURAKAMI, K. Rapid germinability test with exudate from seed. Nature, p.218-493, 1968. 
TAO, J.K. The 1978 "referee" test for soybean and corn. AOSA, Newsletter, v.35, n.4, p.43-66, 1978.

TAO, J.K. An evaluation of alternative methods of accelerated aging seed vigor test for soybeans. Journal Seed Technology, v.3, n.2, p.30 -40 , 1979.

TAO, J.K. Vigor "referee" test for soybean and corn. Proceedings of the Association of Official Seed Analysts, v.54, n.1, p. 40-58, 1980.

TEKRONY, D.M. Seed vigor testing - 1982. Journal Seed Technology, v.8, n.1, p.55-60, 1983.

TEKRONY, D.M.; EGLI, D.B. Relationship between laboratory indices of soybean seed vigor and field emergence. Crop Science, v.17, n.4, p.573577, 1977.

TOLEDO, F.F.; NOVEMBRE, A.D.L.C.; CHAMMA, H.M.C.P.; MASCHIETTO, R.W. Emissão da raiz primária e vigor de sementes de milho (Zea mays L.) Informativo ABRATES, v.5, n.2, p 139, agosto 1995 (Resumo).

TOMES, L.J.; TEKRONY, D.M.; EGLI, D.D. Factors influencing the tray acelerated aging test for soybean seed. Journal Seed Technology, v.12, n.1, p.124-135, 1988.

TRACY, W.F.; JUICK, J.A. Electrolyte leakage and seed quality in shrunken-2 maize selected for improved field emergence. HortScience, v.23, n.2, p.391-392, 1988.

TYAGI, C.S. Evaluating viability and vigour in soybean seed with automatic seed analizer. Seed Science and Technology, v.20, p.687-694, 1992.

VAUGHAN, C.E. Predicting seed longevity. Annual Report of the Bean Improvenment Cooperative, v.14, p.12-16, 1971.

VERMA, V.D.; RAM, H.H. Genetics of electrical condutivity in soybean. Seed Science and Technology, v.15, p.125-134, 1987.

VIEIRA, R.D. Teste de condutividade elétrica. In: VIEIRA, R.D.; CARVALHO, N.M. (Ed.) Testes de vigor em sementes. Jaboticabal: FUNEP, 1994, p.103-132. 
WANG, Y.R.; HAMPTON, J.G.; HILL, M.J. Red clover vigour testing effects of three test variables. Seed Science and Technology, v.22, p.99-105, 1994.

WANN, E.V. Leaching of metabolites during imbibition of sweet corn seed of diferent endosperm genotypes. Crop Science, v.26, p. 731-733, 1986.

WATERS, L.; BLANCHETTE, B. Prediction of sweet corn field emergence by condutivity and cold test. Journal of the American Society of Hortscience, v.108, p.778-781, 1983.

WILSON Jr., D.O. A unified approach to interpretation of single seed conductivity data. Seed Science and Technology, v.20, p.115-163, 1992.

WILSON Jr., D.O.; TRAWATHA, S.E. Physiological maturity and vigor in production of "Florida Staysweet" shrunken-2 sweet corn seed. Crop Science, v.331, p.1640-1647, 1991.

WOLK, W.D.; HERNER, R.C. Chilling injury of germinating seeds and seedlings. HortScience, v.17, n.2, p.169-172, 1982.

ZONTA, E.P.; MACHADO, A.D.; SILVEIRA Jr., P. Sistemas de análise estatistica para microcomputadores- SANEST. Pelotas: UFPel., 1984 (Regristro SEI 06606-0 categoria AO). 
Tabela 1A. Valores médios da precipitação pluvial (mm) e temperaturas $\left({ }^{\circ} \mathrm{C}\right)$ máximas e mínimas semanais. Período de agosto de 1995 a julho de 1996 . (Dados fornecidos no Departamento de Física e Meteorologia da ESALQ. Piracicaba, SP).

\begin{tabular}{|c|c|c|c|c|c|c|c|c|c|c|c|}
\hline Semana & \begin{tabular}{|l|} 
Pçẫo \\
pluvial
\end{tabular} & $\begin{array}{c}\text { T. min } \\
{ }^{\circ} \mathbf{C}\end{array}$ & $\begin{array}{c}\text { T. max } \\
{ }^{\circ} \mathrm{C}\end{array}$ & Semana & \begin{tabular}{|l|} 
Pção \\
pluvial
\end{tabular} & $\begin{array}{c}\text { T. } \min \\
{ }^{\circ} \mathrm{C}\end{array}$ & $\begin{array}{c}\text { T. max } \\
{ }^{\circ} \mathbf{C}\end{array}$ & Semana & $\begin{array}{l}\text { Pção } \\
\text { pluvial }\end{array}$ & $\begin{array}{c}\text { T. } \min \\
{ }^{\circ} \mathbf{C}\end{array}$ & $\begin{array}{l}\text { T. } \max \\
{ }^{\circ} \mathrm{C}\end{array}$ \\
\hline 1 & 1,20 & 12,82 & 26,06 & 19 & 2,60 & 18,50 & 31,80 & 37 & 0,3 & 19,10 & 30,00 \\
\hline 2 & 0,00 & 13,90 & 30,60 & 20 & 47,30 & 17,14 & 28,50 & 38 & 11,7 & 16,30 & 27,80 \\
\hline 3 & 0,00 & 13,30 & 30,82 & 21 & 25,60 & 20,50 & 30,10 & 39 & 0,00 & 13,10 & 28,20 \\
\hline 4 & 0,00 & 12,00 & 30,41 & 22 & 146,7 & 19,25 & 29,20 & 40 & 0,00 & 13,90 & 27,00 \\
\hline 5 & 0,00 & 13,20 & 33,80 & 23 & 163,2 & 19,70 & 27,13 & 41 & 3,3 & 12,80 & 27,20 \\
\hline 6 & 0,00 & 10,93 & 29,23 & 24 & 111,2 & 20,25 & 30,46 & 42 & 28,10 & 13,90 & 26,80 \\
\hline 7 & 0,00 & 14,70 & 31,35 & 25 & 39,20 & 20,51 & 31,94 & 43 & 4,00 & 13,70 & 25,10 \\
\hline 8 & 18,10 & 14,60 & 29,90 & 26 & 1,20 & 20,43 & 32,15 & 44 & 0,00 & 10,10 & 26,30 \\
\hline 9 & 19,50 & 16,14 & 27,63 & 27 & 25,70 & 20,50 & 33,40 & 45 & 5,00 & 11,50 & 23,40 \\
\hline 10 & 9,30 & 16,17 & 31,00 & 28 & 44,10 & 21,00 & 32,00 & 46 & 0,00 & 8,62 & 25,40 \\
\hline 11 & 41,50 & 16,30 & 29,80 & 29 & 23,30 & 19,40 & 31,38 & 47 & 0,00 & 11,50 & 29,80 \\
\hline 12 & 92,70 & 16,20 & 24,30 & 30 & 18,00 & 19,60 & 32,10 & 48 & 18,30 & 12,80 & 24,50 \\
\hline 13 & 10,60 & 15,00 & 31,00 & 31 & 150,1 & 25,70 & 30,90 & 49 & 1,60 & 10,90 & 25,10 \\
\hline 14 & 49,00 & 15,40 & 25,40 & 32 & 77,20 & 19,74 & 29,40 & 50 & 0,00 & 9,70 & 24,90 \\
\hline 15 & 62,20 & 19,00 & 32,96 & 33 & 38,50 & 18,40 & 29,87 & 51 & 0,00 & 6,30 & 25,90 \\
\hline 16 & 48,80 & 18,30 & 27,70 & 34 & 15,70 & 19,44 & 30,00 & 52 & 0,70 & 9,60 & 24,60 \\
\hline 17 & 28,10 & 15,10 & 29,10 & 35 & 12,20 & 19,64 & 32,36 & 53 & 0,00 & 11,1 & 23,50 \\
\hline 18 & 3,30 & 17,54 & 32,60 & 36 & 0,00 & 19,40 & 33,18 & - & - & - & - \\
\hline
\end{tabular}


Tabela 2A. Valores médios da umidade relativa do ar (\%) e temperaturas médias, máximas e mínimas $\left({ }^{\circ} \mathrm{C}\right)$ por decêndio. Período de janeiro a agosto de 1996 . (Dados obtidos no LAS do Departamento de Agricultura da ESALQ. Piracicaba, SP).

\begin{tabular}{cccccc}
\hline Mês & $\begin{array}{c}\text { Decêndio } \\
\text { janeiro }\end{array}$ & $\begin{array}{c}\text { U. relativa } \\
(\%)\end{array}$ & $\begin{array}{c}\text { T. média } \\
\left({ }^{\circ} \mathrm{C}\right)\end{array}$ & $\begin{array}{c}\text { T. máxima } \\
\left({ }^{\circ} \mathrm{C}\right)\end{array}$ & $\begin{array}{c}\text { T.mínima } \\
\left({ }^{\circ} \mathrm{C}\right)\end{array}$ \\
\hline \multirow{5}{*}{ fevereiro } & 1 & 85,90 & 23,57 & 24,60 & 21,10 \\
& 2 & 73,99 & 25,97 & 28,90 & 23,30 \\
& 3 & 73,06 & 30,72 & 31,10 & 22,80 \\
março & 5 & 74,99 & 26,21 & 29,40 & 22,80 \\
& 6 & 72,53 & 25,42 & 28,90 & 22,80 \\
& 7 & 79,99 & 25,25 & 27,80 & 22,80 \\
abril & 8 & 78,70 & 23,37 & 27,80 & 20,60 \\
& 9 & 72,49 & 24,04 & 27,80 & 21,10 \\
& 10 & 77,80 & 26,82 & 29,40 & 22,80 \\
maio & 11 & 73,53 & 23,08 & 28,90 & 23,30 \\
& 12 & 66,23 & 22,25 & 26,70 & 17,70 \\
& 13 & 68,99 & 20,84 & 24,00 & 17,80 \\
junho & 14 & 75,43 & 19,98 & 25,00 & 15,60 \\
& 15 & 73,54 & 18,62 & 21,70 & 14,40 \\
& 16 & 73,25 & 17,78 & 19,84 & 15,32 \\
julho & 17 & 68,10 & 19,40 & 21,77 & 14,90 \\
& 18 & 70,90 & 18,61 & 21,07 & 16,01 \\
& 19 & 77,90 & 18,79 & 21,45 & 16,07 \\
agosto & 20 & 65,70 & 17,58 & 18,40 & 11,60 \\
& 21 & 65,67 & 17,20 & 19,72 & 15,55 \\
& 22 & 59,10 & 18,72 & 22,16 & 14,27 \\
& 23 & 67,00 & 19,10 & 22,28 & 15,16 \\
& 24 & 57,63 & 23,16 & 26,10 & 19,03 \\
\hline \hline
\end{tabular}


Tabela 3A. Número de sementes com emissão de raiz primária ( PER ) durante os períodos de exposição no germinador a 20,25 e $30^{\circ}$, dos vinte lotes de milho híbrido AG-510. Piracicaba, SP. 1996

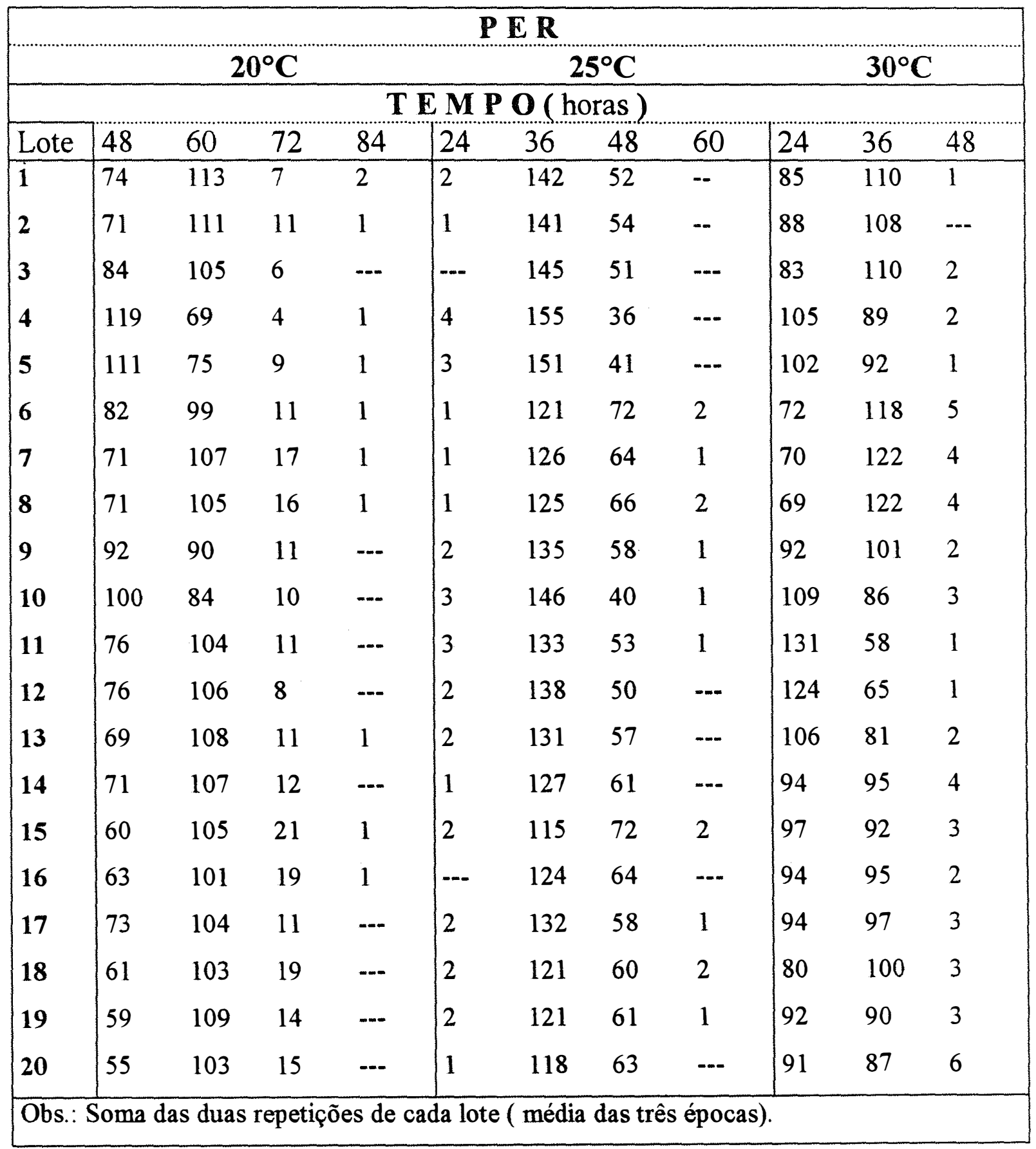

